\title{
The potential of the Sudetes Mountains for the development of geotouristic products
}

\section{Potencjał regionu Sudetów w kreowaniu produktów geoturystycznych}

\author{
Mateusz Rogowski \\ Adam Mickiewicz University, Poznań, Tourism and Recreation Department, \\ ul. Dzięgielowa 27, 61-680 Poznań; \\ e-mail:mateusz.rogowski@amu.edu.pl
}
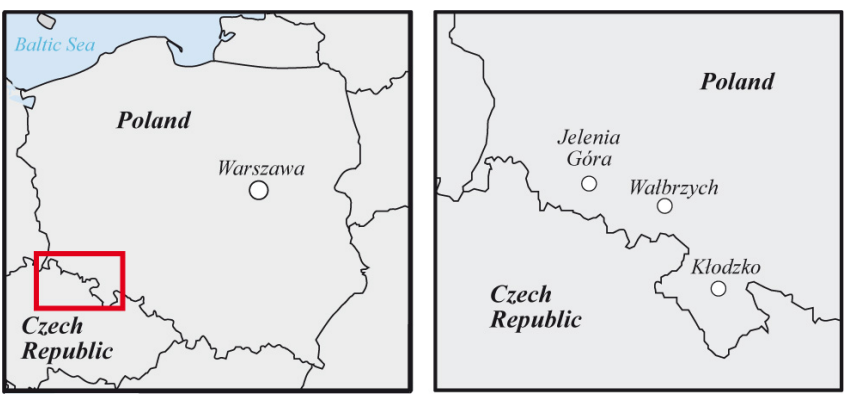

Abstract: The Sudetes Mts. have a large potential where geotourism can develop, because of their most diverse geological structure and landforms in Poland. It is essential to perform a complete diagnosis of the geotouristic potential within this region. Up until now, different kinds of activities were developed in this region associated with geotourism, such as the establishment of associations, creation of educational footpaths, thematic maps, flyers, educational centers and a geopark. The aim of this paper is to present the potential of the Sudetes Mountains as geotouristic products. "First-rate" regions can be distinguished with defined offers. Thanks to these offers, a trans-border geotourist product network can be created.

Key word: geotourism, geotourist product, geotourist region, Sudetes Mts.

Treść: Wspótcześnie coraz częściej gospodarczy rozwój regionu rozpatrywany jest przez pryzmat turystyki. Sudety maja duży i różnorodny potencjal turystyczny, a rozwój geoturystyki zwiazany jest ze zróżnicowana budowa geologiczna i rzeźba terenu. Potencjat ten może zostać wykorzystany $w$ kreowaniu produktów geoturystycznych. W przypadku tych regionów podejmowane sq coraz bardziej widoczne inicjatywy, którymi sq m.in. lokalne grupy działania, stowarzyszenia, ośrodki edukacyjne, geoparki, szlaki dydaktyczne oraz opracowania krajoznawcze. W wyniku określonych działań powstaje specyficzny produkt turystyczny przeznaczony dla geoturystów. Celem artykułu jest przedstawienie potencjału regionu Sudetów stużacego do kreowania produktów geoturystycznych, z wyróżnieniem najistotniejszych $w$ tym względzie regionów. Natomiast dzięki takiej ofercie można wykreować transgraniczny, sieciowy produkt turystyczny.

Stowa kluczowe: geoturystyka, produkt geoturystyczny, region geoturystyczny, Sudety

\section{Introduction}

Tourism is a global phenomenon and is developing very intensively, growing from year to year. Along with this growth, the motives of tourism are more and more different. These motives correspond with re-discovering famous regions based on "new subjects" and exploring unknown regions.

More specialist tourist preferences develop new knowledge and educational functions of an area with new technologies and more active visiting forms. This corresponds to a trend. Accordingly, tourism has evolved from the traditional " 3 x S" (Sea, Sun, Sand) to "3 x E" (Entertainment, Excitement, Education). The desire to enjoy new experiences, feel unique emotions and take certain actions prevails now. The destination marketing will be broadly oriented towards this (Tourism 2020..., 2001).

Relatively recent types of tourism include geotourism, which corresponds to the " 3 x E" trends. The Sudety Mts. is a highly attractive region for geotourism because of its diverse geological structure, types of landforms and numerous mining sites. This region contains different types of natural and cultural mountain landscapes.

The aim of this paper is to present the potential of the Sudetes Mountains related to the creation of geotourist products.

"First-rate" regions can be distinguished within the Sudetes They provide defined offers, which can create a trans-border geotourism product network.

"Geotourism" was defined for the first time by Hose (1995), who emphasized the difference between leisure tourism, directed towards recreation and psychophysical regeneration, and the cognitive tourism, directed towards gaining the knowledge of the visited destinations. "A form of natural area tourism that specifically focuses on landscape and geology. It promotes tourism of geosites and the conservation of geo-diversity and an understanding of Earth sciences through appreciation and learning. This is achieved through independent visits to geological features, use of geo-trails and viewing points, guided tours, geo-activities and patronage of geosite visitor centers" (Newsome, Dowling, 2010).

"The provision of interpretive and service facilities to enable tourists to acquire knowledge and understanding of the geology and geomorphology of a site (including its 
contribution to the development of Earth sciences) beyond the level of mere aesthetic appreciation" (Hose, 1995).

"Geo-" in geotourism is connected to geology, geomorphology and landscape natural features. Natural heritage is related to geodiversity, which is commonly understood as diversification of abiotic elements of the natural environment, i.e. geological structures, landforms, soil types, ground- and surface waters, climate and natural processes (Gray, 2004; Kozłowski et al., 2004). Geosites are geotouristic destinations, where geological and geomorphological forms and processes can be admired (Migoń, 2012a). The landscape features have scenic values, which help in understanding and interpreting geological and geomorphological phenomena and can be photographed and admired. For these reasons, Newsome and Dowling (2010) indicate a strong connection between "geotourism" and "landscape tourism" ("turystyka krajobrazowa" of Andrejczuk, 2010). According to Mateo-Rodriguez (2003) "landscape tourism" is a high-level product, which is prepared for discovering a landscape, field watching and understanding natural and cultural features with a link to sustainable development.

\section{Geotouristic product as a new regional offer}

Touristic product in its broad sense is a combination of what tourists do and the assets, devices and services which they use for this purpose (Medlik, 1995). A similar view is presented by Kaczmarek et al. (2010), who define the touristic product as a "set of utilities related to touristic trips, i.e. touristic goods and services available on the market, enabling people to plan a journey, travel and collect experiences".

The touristic product in a strict sense is a very complicated item, comprising numerous and various elements: both material (including amenities) and immaterial goods, values and services. All these elements should be linked by one main idea (i.e. an idea of a product), and also by an adequate and efficient organization providing logistic security, professional "production", selling etc. The touristic product depends mainly on its organizer (i.e., their professionalism, reliability, quality of services etc.) (Kaczmarek et al., 2010).

The geotouristic product is defined by several authors. According to Farsani et al. (2012) and Migoń (2012a) it is created and purchased by man and; it is sustainable product, which integrates traditional products with new concepts and interpretations, it stimulates the local economy and promotes geotouristic destinations, and it is an educational and protective tool, which uses its geological attraction.

In the literature, a geoproduct is presented as the core of the geotouristic product. (Dryglas, Miśkiewicz, 2014). Equally important to ,a core" of a product (i.e. purchased package of values and services) are its environment, weather during holidays, new acquaintances made while travelling, general atmosphere of a trip, feelings of participants, new experiences gained, and the image of the beauty spot.

A geotouristic product is a composition of a geo-product and the concept of tourism. Thus, geotouristic products are tangible and intangible geo-products developed on the basis of abiotic nature, co-created (knowledge and craft) and experienced in connection with travel outside the place of residence, both before travel, during its duration, as well as during the geotourist's stay and after his return, enabling the fulfillment of geotouristic purposes (Dryglas, Miśkiewicz, 2014).

A geotouristic product is a very complex issue that cannot be identified only with the supply of services and geotouristic attractions gathered in the investigated area. In order to talk about the geotouristic product, elements of geotouristic supply should be subordinated to the common concept aiming to satisfy the needs of tourists and implemented by one of the five items: package geo-tour organizers, local self-government, manufacturers of individual geotouristic products, local community and the tourists themselves (Dryglas, 2012).

Universal characteristics of the touristic product:

- the essence of a touristic product - comprises the basic needs of tourists (e.g. the need for rest, learning something new strictly connected with the motives of travelling),

- real (tangible) product - is an actual market offer stating what the client gets for his money, it comprises all standard elements of a tour package enabling the realization of the essence of a touristic product (fulfilling tourists' need),

- extended product (enriched, enlarged, improved) - contains additional services included in a tour offered, increasing its attractiveness (Kaczmarek et al., 2010).

The principal objective of geotourism is the transformation of geological characteristics of a region into a touristic product. This objective can be achieved by the following assignments:

- a popularization - promotion and presentation of geological heritage with the application of various media techniques,

- education - implementation of Earth sciences at all levels of teaching,

- research and development - preparation of research methods, tools and techniques,

- protection - security and conservation of geosites by proper management,

- design - preparation of geosites as tourist destinations,

- organization - preparation and guidance of geotouristic trips, meetings, conferences, etc.,

- training - preparation of the personnel for geotouristic services (Miśkiewicz et al., 2007).

Within the geotouristic product types, we can distinguish simple and complex geo-products that pass into and overlap each other in order to create different categories having material and immaterial content. From the hierarchical structure of geo-products defined by Dryglas and Miśkiewicz (2014) in the Sudetes we can distinguish the following:

- a place - the first-rate subregions which embrace all of the above types of geo-products,

- a trail - geo-educational pedestrian trails, auto- route trail,

- a service - geotouristic guided trips,

- an entity - mining museums and geo-centers,

- an object - printed materials, geo-guidebooks and geomaps (Tab. 1). 
Tab. 1. The hierarchical structure of material and immaterial categories of geoproducts (after: Dryglas, Miśkiewicz, 2014) • Struktura hierarchiczna materialnych i niematerialnych kategorii produktów geoturystycznych (za: Dryglas, Miśkiewicz, 2014)

\begin{tabular}{|c|c|c|}
\hline & & $\begin{array}{l}\text { Geo-products } \\
\text { Produkty geoturystyczne }\end{array}$ \\
\hline $\begin{array}{l}\text { Types } \\
\text { Typy }\end{array}$ & $\begin{array}{l}\text { Categories } \\
\text { Kategie }\end{array}$ & $\begin{array}{l}\text { Examples from Poland } \\
\text { Przykłady z obszaru Polski }\end{array}$ \\
\hline \multirow{4}{*}{$\begin{array}{l}\text { Basic } \\
\text { Prosty }\end{array}$} & $\begin{array}{l}\text { Object } \\
\text { Przedmiot }\end{array}$ & $\begin{array}{l}\text { printed materials: geotourist and geological guides, catalogues of geotourist objects, geotourist/ } \\
\text { tourist-geological maps, geo-teaching aids, albums, magazines, brochures, postcards, etc. } \\
\text { materiały drukowane: przewodniki geoturystyczne i geologiczne, katalogi obiektów geoturystycznych, } \\
\text { mapy geoturystyczne, pomoce naukowe, albumy, magazyny, broszury, pocztówki itd. } \\
\text { virtual materials/multimedia: geo-information websites, geotourist virtual tours, geo-applications, } \\
\text { CD, DVD etc. } \\
\text { materiały wirtualne i multimedia: strony geoinformacyjne, geoturystyczne wycieczki wirtualne, } \\
\text { geoaplikacje itd. } \\
\text { geo-interpretative panels / panele geointerpretacyjne } \\
\text { collections of rocks, minerals and fossils / kolekcje skał, minerałów i skamieniałości } \\
\text { handicraft e.g. jewellery, geo-cosmetics, geo-decoration, bottled water, glassware, metalwork / } \\
\text { rękodzielnictwo, np. biżuteria, geokosmetyki, geodekoracja, woda butelkowana, szkło, metaloplastyka }\end{array}$ \\
\hline & $\begin{array}{l}\text { Entity } \\
\text { Miejsce }\end{array}$ & $\begin{array}{c}\text { permanent exhibition e.g. / ekspozycje stałe np.: } \\
\text { geological and paleontological museums / muzea geologiczne i paleontologiczne, } \\
\text { geo-centres / geocentra edukacyjne } \\
\text { stone in architecture / kamień w architekturze } \\
\text { mining facilities / obiekty górnicze } \\
\text { erratic boulder park / głazy narzutowe }\end{array}$ \\
\hline & $\begin{array}{c}\text { Event } \\
\text { Wydarzenie }\end{array}$ & $\begin{array}{l}\text { temporary exhibitions such exhibitions and markets of minerals and jewellery products / } \\
\text { ekspozycje czasowe, takie jak wystawy i targi minerałów i wyrobów jubilerskich } \\
\text { geological picnics / pikniki geologiczne } \\
\text { geological festivals / festiwale geologiczne } \\
\text { competitions geological knowledge / konkursy wiedzy geologicznej } \\
\text { geo-presentations: lectures, broadcasts movies, etc. / geoprezentacje: wykłady, filmy itd. } \\
\text { geo-conferences / geokonferencje }\end{array}$ \\
\hline & $\begin{array}{l}\text { Service } \\
\text { Usługi }\end{array}$ & $\begin{array}{c}\text { geo-guide services / geousługi przewodnickie } \\
\text { geo-training services / geoszkolenia } \\
\text { geo-education services / geoedukacja } \\
\text { geo-information services / geoinformacja } \\
\text { geo-sales services / sprzedaż geoproduktów } \\
\text { geo-medical services e.g. balneotherapy, halotherapy, lithotherapy / } \\
\text { geousługi medyczne: balneoterapia, haloterapia, litoterapia }\end{array}$ \\
\hline \multirow{3}{*}{$\begin{array}{l}\text { Complex } \\
\text { Złożony }\end{array}$} & $\begin{array}{l}\text { Tourism } \\
\text { package } \\
\text { Pakiet } \\
\text { turystyczny }\end{array}$ & $\begin{array}{l}\text { package geo-tours / pakiety geowycieczek } \\
\text { geo-school camps / obozy geoturystyczne } \\
\text { outdoor geo-games e.g. questing / gry geoturystyczne }\end{array}$ \\
\hline & $\begin{array}{l}\text { Trail } \\
\text { Szlak }\end{array}$ & $\begin{array}{c}\text { geotourist trail / szlaki geoturystyczne } \\
\text { geostrada / trasa geoturystyczna } \\
\text { educational trails / szlaki edukacyjne } \\
\text { underground mining tour / podziemne wycieczki }\end{array}$ \\
\hline & $\begin{array}{l}\text { Place } \\
\text { Obszary }\end{array}$ & $\begin{array}{l}\text { UNESCO geoparks / geoparki UNESCO } \\
\text { national geoparks / geoparki krajowe } \\
\text { geological parks / parki geologiczne } \\
\text { dino-parks / parki dinozaurów } \\
\text { spas / ośrodki spa } \\
\text { geo-regions / georegiony }\end{array}$ \\
\hline
\end{tabular}




\section{The geotouristic potential of Sudetes Mts.}

The Sudetes is a mountain range in Central Europe and an area of remarkable geodiversity. In recent years, the area has been promoted as a geotouristic destination. Various initiatives were aimed at better understanding of its geoheritage (Migoń, 2014a). All Sudetes Mts. cross-border regions have the possibilities for geotouristic development, but two areas are cradles of local nature-based tourism. These are the granite massif of the Karkonosze Mts., in the west, and the sandstone stepped plateau of Broumov Highland and Stołowe Mountains, in the central part of the Sudetes (Migoń, 2014a). After initial review, two types of regions with the potential touristic development can be distinguished:

- the "first-rate" regions with highest geotouristic values and best developed infrastructure, leaders of geoturism in the Sudetes Mts. (Karkonosze Mts., Kaczawskie Mts. and Kaczawa Upland, Stołowe Mts., with a BroumovHighland),

- the "second-rate" regions with a high potential and poor geotouristic recognition (Kamienne Mts., Wałbrzyskie Mts., Śnieżnik Massif, High Jesenik, Opawskie Mts., Łużyckie Mts.) (Rogowski, 2014).

Main geotouristic values, located in the Sudety Mts., are:

- mountain postglacial landforms,

- relicts of volcanic activity during different geological periods,

- rocks and labyrinths ("rock cities") of sandstone, granites and gneisses,

- Niedźwiedzia (Bear) Cave in Kletno,

- river gorges of Nysa Kłodzka, Pełcznica and Bóbr,

- gold mines in Złotoryja, Złoty Stok and coal mines in Nowa Ruda and Wałbrzych,

- cyclical events: Agate Summer in Lwówek (Lwóweckie Lato Agatowe), International Gold Panning Competition (Międzynarodowe Mistrzostwa Polski w Płukaniu Złota) in Złotoryja.

The values, with potential to enable the creation of geotouristic product in the Sudetes region are:

- geotouristic values - abiotic geological and geomorphological features, mining sites and various subtypes of cultural landscapes; these values were described and protected against degradation and weeds over-growth;

- geotouristic infrastructure - makes available and protects geotouristic values (educational paths with boards, observation points, footbridges, ladders and barriers);

- the idea, connected with creating a geotouristic yearly destination image of the Sudetes Mts. with large geodiversity and different types of cultural landscape and easy accessibility;

- consolidation of activities and good organization into a cohesive, recognizable and positive image, to follow potential geotourists' needs

The cooperation of various touristic services, organizations and higher education institutions creating a network and establishing a cluster.

All indicated above geoproducts can be defined in the $\mathrm{Su}-$ dety Mts.

\section{A geotouristic product - a place}

\section{The Karkonosze Mountains}

The Karkonosze Mts. is the highest and largest range in the Sudetes. It is a mountainous region that is among the most valuable landscapes and natural habitats of Central Europe. This range is protected by the Bilateral Biosphere Reserve Karkonosze/Krkonoše UNESCO/MaB Polish and Czech Karkonosze National Park. The Certificate of a National Geopark was awarded in 2010 (Knapik, Migoń, 2010).

The Karkonosze Mts. geodiversity includes a variety of geological, mineralogical and geomorphological phenomena, mining remnants and cultural landscapes. Many of the natural phenomena, according to Knapik et al. (2011) make the Karkonosze Mountains an exceptional area in Poland, and of outstanding value within Europe., This range represents (Štursa, 2013) a Hercynian middle-mountains landscape. The value of abiotic nature is promoted through multiple activities in the field of geotourism and ecological education, including construction of an extensive network of geosites, marked tourist paths, and educational trails with information boards. Further promotion of geodiversity of the Karkonosze is carried out in cooperation with the adjacent Krkonošský narodní park on the Czech side of the mountains, aimed at the establishment of the bilateral Polish-Czech Geopark Krkonoše/Karkonosze (www 1), within the framework of the European Geopark Network (Knapik et al., 2011). The aesthetic values were categorized by Wyrzykowski et al. (1991), as a first class landscape with greatest visual values connected with relief and land cover.

Geotouristic values of the Karkonosze Mts. were the subject of comprehensive scientific assessment by Knapik et al. (2011). The geosites with the best marks are: Small Snow Cirque (Mały Śnieżny Kocioł), Owl Valley (Sowia Valley), Mt. Rocky Table (Skalny Stół), Great Snow Cirque (Wielki Śnieżny Kocioł), and Rock Pilgrims (Pielgrzymy), Small Lake Cirque (Kocioł Małego Stawu) Mt. Śnieżka (Śnieżka). Anadditional study was performed by Rogowski et al., (2013). He assigned the best marks to Mt. Śnieżka, cirque of a Small Lake, Mt. Chojnik, Kamieńczyk waterfall and gorge, Szklarka waterfall, Cicha Valley, Równia pod Śnieżką (Under Mt. Śnieżka Plane), Biały Jar, Sowia Valley (Owl Valley), Łomniczka cirque, Mały Śnieżny Kocioł (Small Snowing Cirque).

The geotouristic infrastructure of the Karkonosze Mts. contains educational centers, educational paths, guidebooks, maps and geotouristic trips and workshops. The Centre of Ecological Education in the Karkonosze National Park (Centrum Edukacji Ekologicznej Karkonoskiego Parku Narodowego) in Szklarska Poręba and permanent ecological expositions in Vrchlabi were established. They present the abiotic nature of the Karkonosze Mts. Interactive presentations show among other things postglacial kettles, peat bogs and natural phenomena and the influence of humans on the mountains The network of 13 educational paths with panels present various geotouristic issues like geological, mineralogical and geomorphological features and post-glacial transformation of mountain relief in the Karkonosze Mts and around Karpacz and Szklarska Poręba.

The park staff offers geotouristic trips and workshops for every tourist, mainly for school groups. The geotouristic guidebook by Knapik (2008), an atlas (Atlas Georóżnorodność..., 2011) and a book about the Karkonosze landscape and rocks (Migoń, 2012b) were published. 

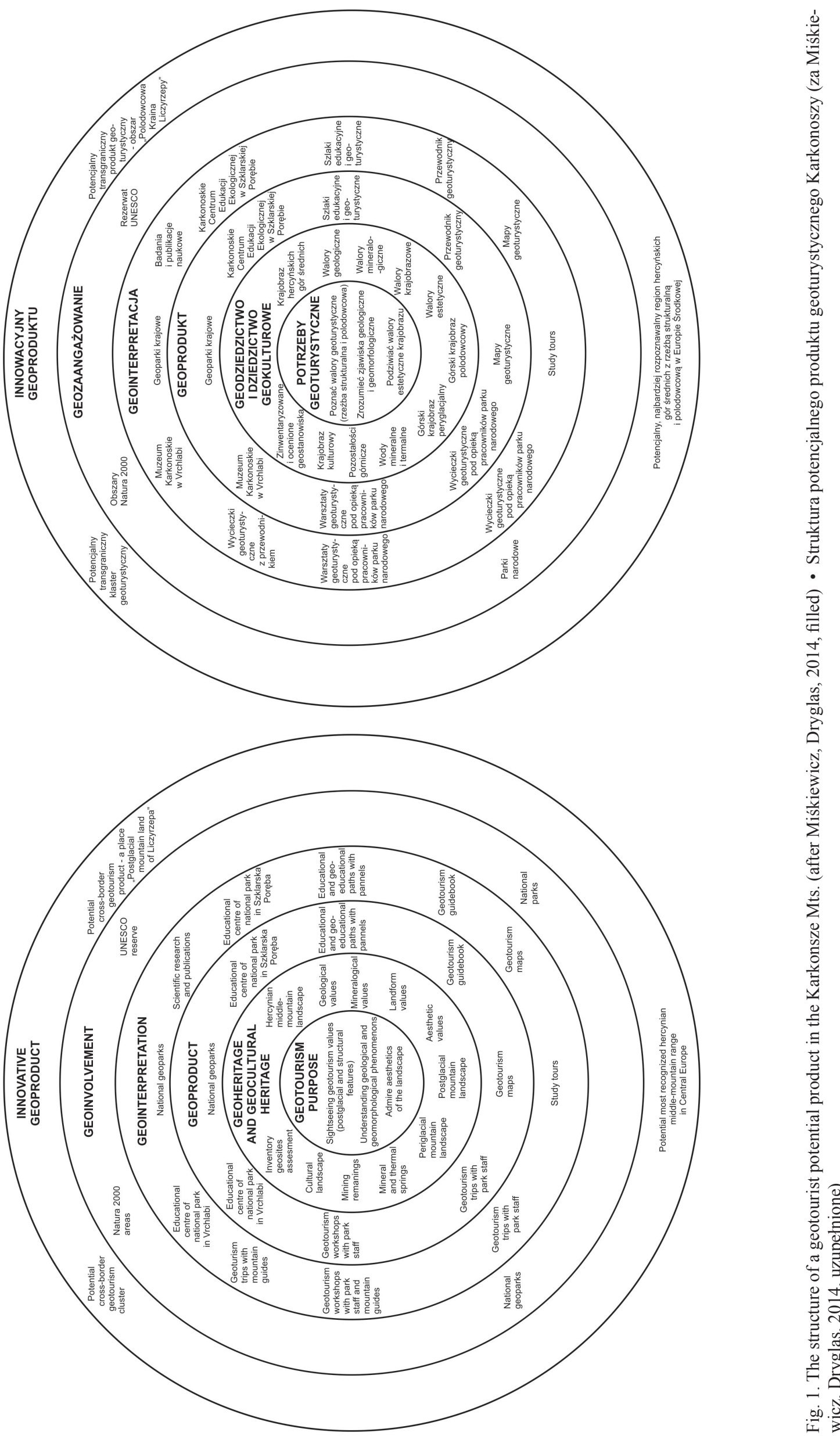
The Polish and Czech geoparks, national parks with common logo, identity and park staff with various cooperation levels are examples of integration. Good identification of this region can serve as attribute useful in creating a cohesive geotouristic product. In the future, the Karkonosze Mts., a cross-border geotourism product will be a place with the name Postglacial Land of Liczyrzepa (Polodowcowa Kraina Liczyrzepy), which will show the existing Pleistocene mountain glacier in the highest part of the Sudetes Mts. Thanks to this product, the Karkonosze Mts. will become the best recognized region in the Hercynian mountain system in Europe (Figs 1, 2).

\section{The Land of Extinct Volcanoes}

The Kaczawskie Mts. and Kaczawa Foothills are parts of the West Sudetes Mts., rich in geoheritage properties. Geodiversity of this area includes geological, mineralogical and geomorphological features connected to volcanism in the Sudetes, gold-mining and quarry remnants and cultural landscapes. The aesthetic values were categorized by Wyrzykowski et al. (1991) as second class landscapes, with the greatest visual values connected to relief and land cover. According to Pijet-Migoń and Migoń (2009), this geodiversity reveals long geological history, and a variety of rocks of different age and origin and landforms. Among them, vestiges of ancient volcanism are widespread, including ones from the latest phase of volcanism in the Sudetes, dated back to the middle Cenozoic. Collectively, they provide insight into the geological evolution of the area and are very important scientifically (www 2). However, many also possess outstanding scenic qualities. Some exhibit forms of distinctive conical and domed hills, which are characteristic landmarks of the regional landscape (e.g. volcanic plug Ostrzyca or Grodziec). In others, natural processes or quarrying have exposed the internal structure of a volcanic body, particularly the regular columnar jointing (e.g. Ostrzyca, Wilcza Góra, Czartowska Skała) (Pijet-Migoń, Migoń, 2009). Most valuable areas are covered with geological and landscape reserves and the Landscape Park "Chełmy".

The geotouristic values, potential and possibilities of geotouristic development in region were characterized by Pijet-Migoń, Migoń (2009) and Migoń, Pijet-Migoń (2010). The geotouristic potential of Wojcieszów sub-region was described by Mianowicz and Brzozowska (2009). Różycka (2014) indicated seventy potential geotouristic attractions. They represent different types of objects such as tors, quarries, caves, lime kilns, remnants of past metalliferous mining, stone-made buildings, gravel-sand pits, viewing points, springs, an anthropogenic lake, river channel, erratic boulders. Cedro et al. (2009) assessed geosites giving the best note to: Mt. Wolf (Wilcza Góra), Wielislawskie Organs (Organy Wielisławskie), and Myśliborski Gorge (Wąwóz Myśliborski).

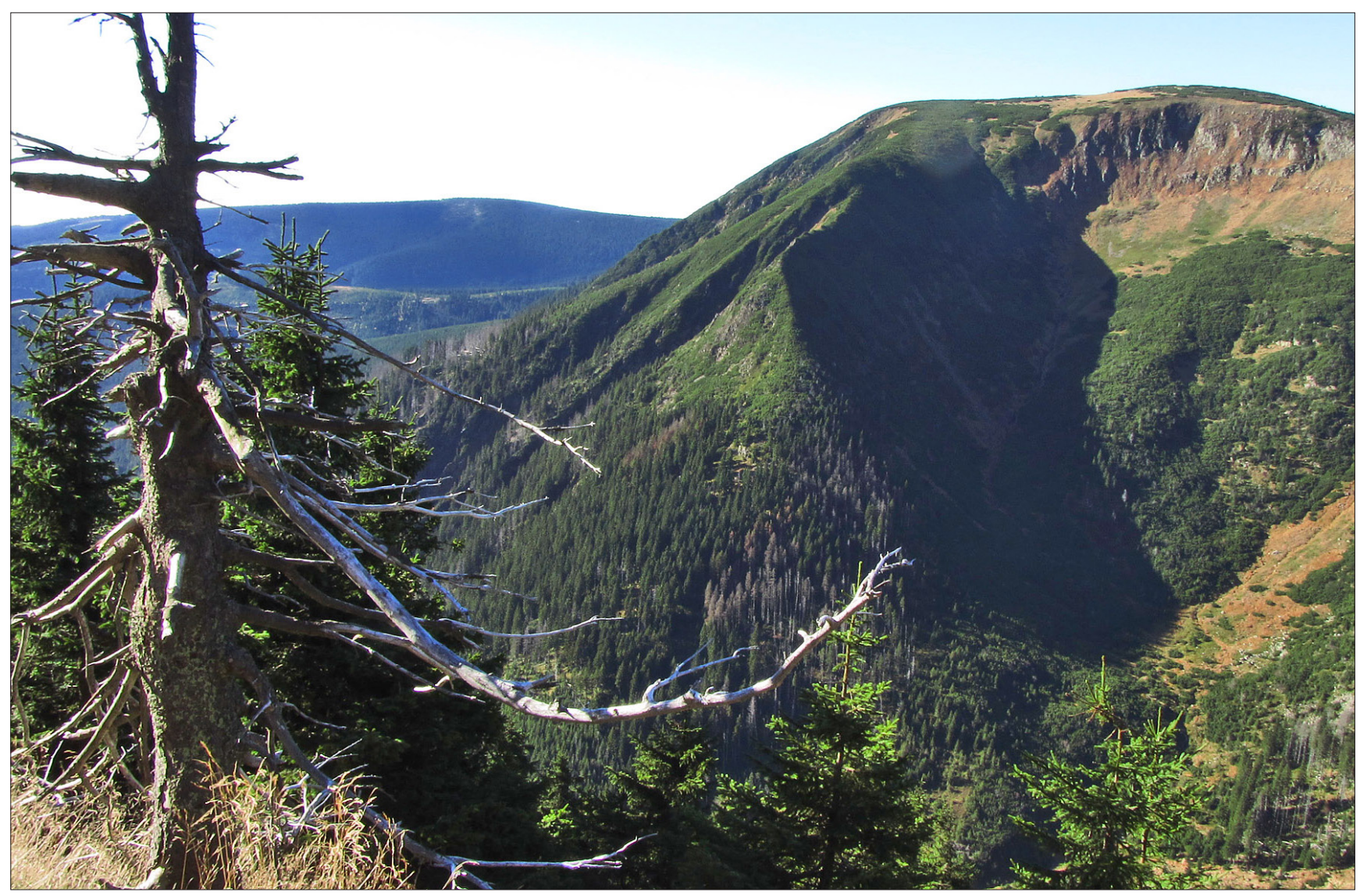

Fig. 2. Studnicni Hora and Obri Dul - the postglacial heritage of the Giant Mts., photo M. Rogowski • Studnicni Hora i Obri Dul - polodowcowe dziedzictwo Karkonoszy, fot. M. Rogowski 

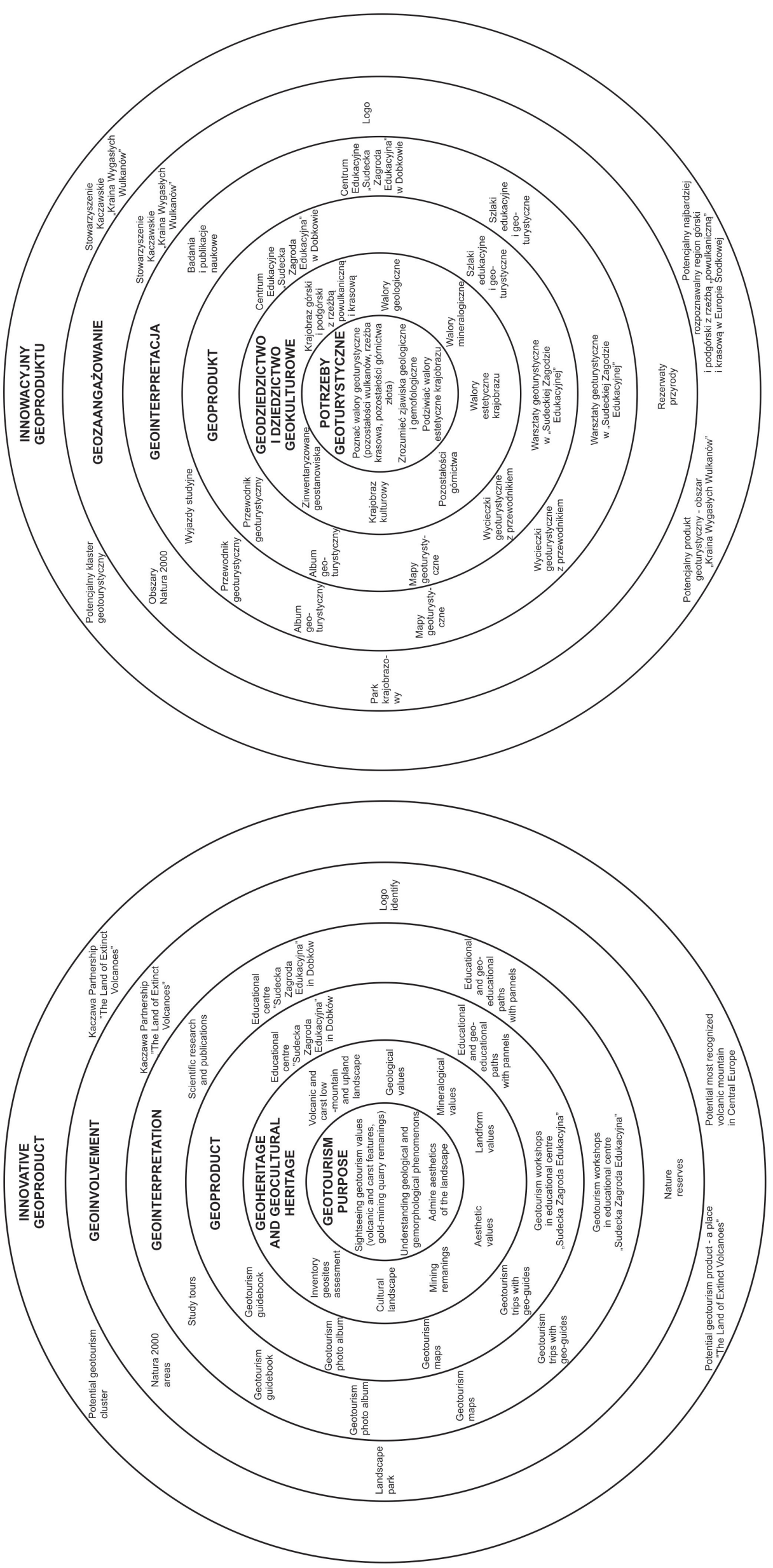

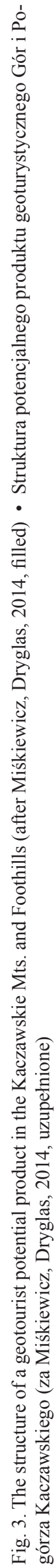


The sightseeing of three mining objects - Goldmine "Aurelia", gold museum in Złotoryja, open-air gold museum in Leszczyna - and two events, the international Agate Summer in Lwówek (Lwóweckie Lato Agatowe) and the International Gold Panning Competition (Międzynarodowe Mistrzostwa Polski w Płukaniu Złota) are important elements of the geoturistic offer of the region (www 3). Other geotourism infrastructure is created by 11 educational paths and 2 tourist furnished educational panels. In 2014, geotouristic materials: guidebook, geotouristic map and photography album were published.

In a recent project aimed at economic development of the area and carried out since 2004 by the Kaczawa Partnership (Partnerstwo Kaczawskie), the phrase "In the Land of Extinct Volcanoes" has been chosen as a label, through which the region would be identified. Cooperation between participants is developing, and finally a cluster can be established. Thanks to this initiative, an ecomuseum, workshops and geotourism trips were created. The most significant initiative is The Sudecka Education Centre in Dobków (Sudecka Zagroda Edukacyjna), which will be focused on volcanic phenomena and cultural landscape of the Sudetes Mts.

The geotourism potential of The Land of Extinct Volcanoes (Kraina Wygasłych Wulkanów) is being used in various initiatives to strengthen the tourist offer on the international tourism market. This region can be developed as a geotouristic product - a place, which will become one of the recognized volcanic areas in Central Europe (Figs 3, 4).

\section{The Stolowe Mts.}

The Stołowe Mts. is one of the most famous touristic subregions in the Sudetes Mts., located along the Polish- Czech border. This region is a distinctive landscape unit in the central part of the mountain range of the Sudetes, which forms an extended tract of diverse relief, about $300 \times 80 \mathrm{~km}$ in dimension, occuring along the north-eastern rim of the Bohemian Massif in Central Europe (Migoń, 2012c). Three horizontal rocky layers build these mountains:

- 850-919 $\mathrm{m}$ - the highest bastions built of upper joint sandstones - Szczeliniec Wielki, Szczeliniec Mały, Skalniak and Narożnik,

- 500-800 m - middle plateau of Karłów and Łężyce, covered by marls,

- 400-500 m - the lowest level in the south-eastern part.

The geoheritage and its development has determined some sub-regions: Adršpašsko-Teplické rocks and Ostaš, Broumovské Stěny, Błędne Skały and Szczeliniec Wielki. Most valuable areas are located within the national park, in natural reserves and the protected landscape area. The aesthetic values were categorized by Wyrzykowski et al. (1991) as a first class landscape, with the greatest visual values including relief and land cover.

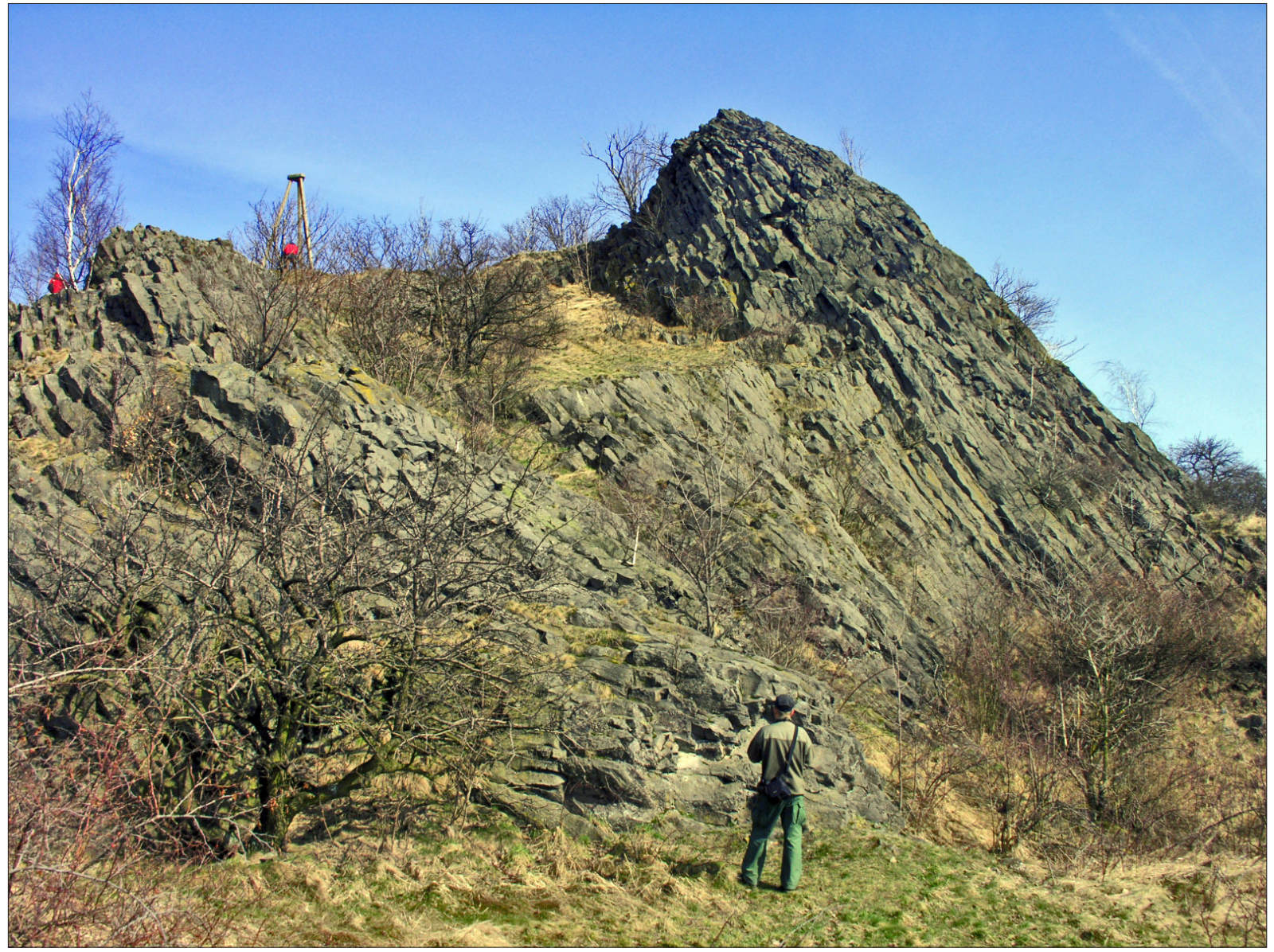

Fig. 4. Devil's Rock - the neck, meaning the remnant of a volcanic chimney, photo M. Rogowski • Czartowska Skała - nek będący pozostałością komina wulkanicznego, fot. M. Rogowski 

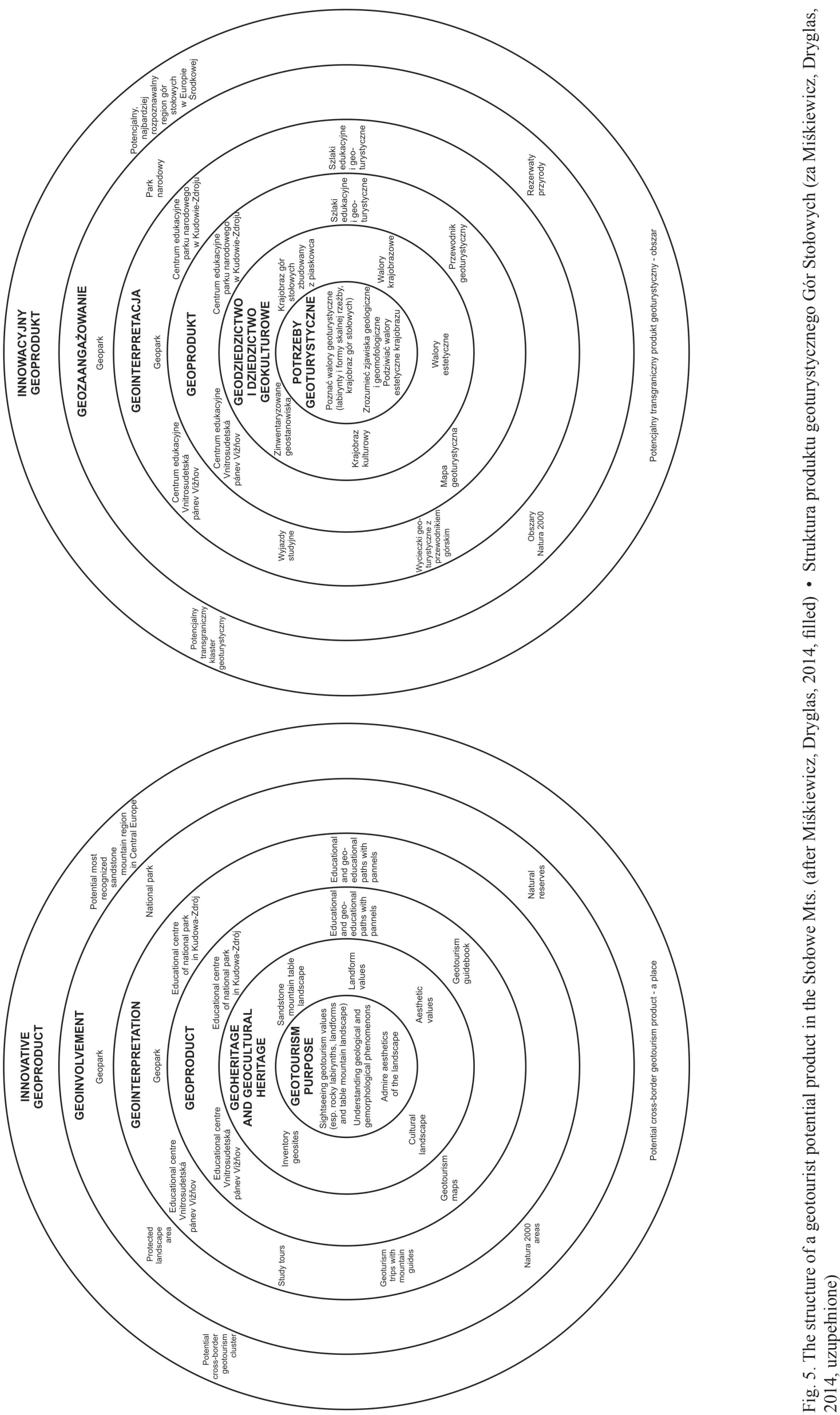
The Stołowe Mts. geodiversity includes geomorphological features of major and minor landforms in the sandstone landscape. These geovalues were described in two guidebooks by Wojewoda (2011) and Wojewoda ed. (2013), and in a geological-tourist map by Cech and Gawlikowska (1999) and Wojewoda (2013). In the Czech part, an initiative Broumovsko Geopark was created, and for its needs, 44 geosites were described (www 4).

The geotourist infrastructure composes of 9 educational paths with educational panels, a guidebook of Geoattractions of the Stolowe Mts. and a map and educational center Geopark Vnitrosudetská pánev - Vižňov u Muziměstí mainly destined for kids (www 5).

The Stołowe Mts. region will become a geoturistic product despite the lack of a common initiative. There are no cross-border coordination activities. On the Polish part, there is a national park. On the Czech part, a partnership Broumovsko Geopark exists. There is a chance for the Stołowe Mts. cross-border region to become the most recognized sandstone landscape region in Central Europe (Figs 5, 6, 7, 8).

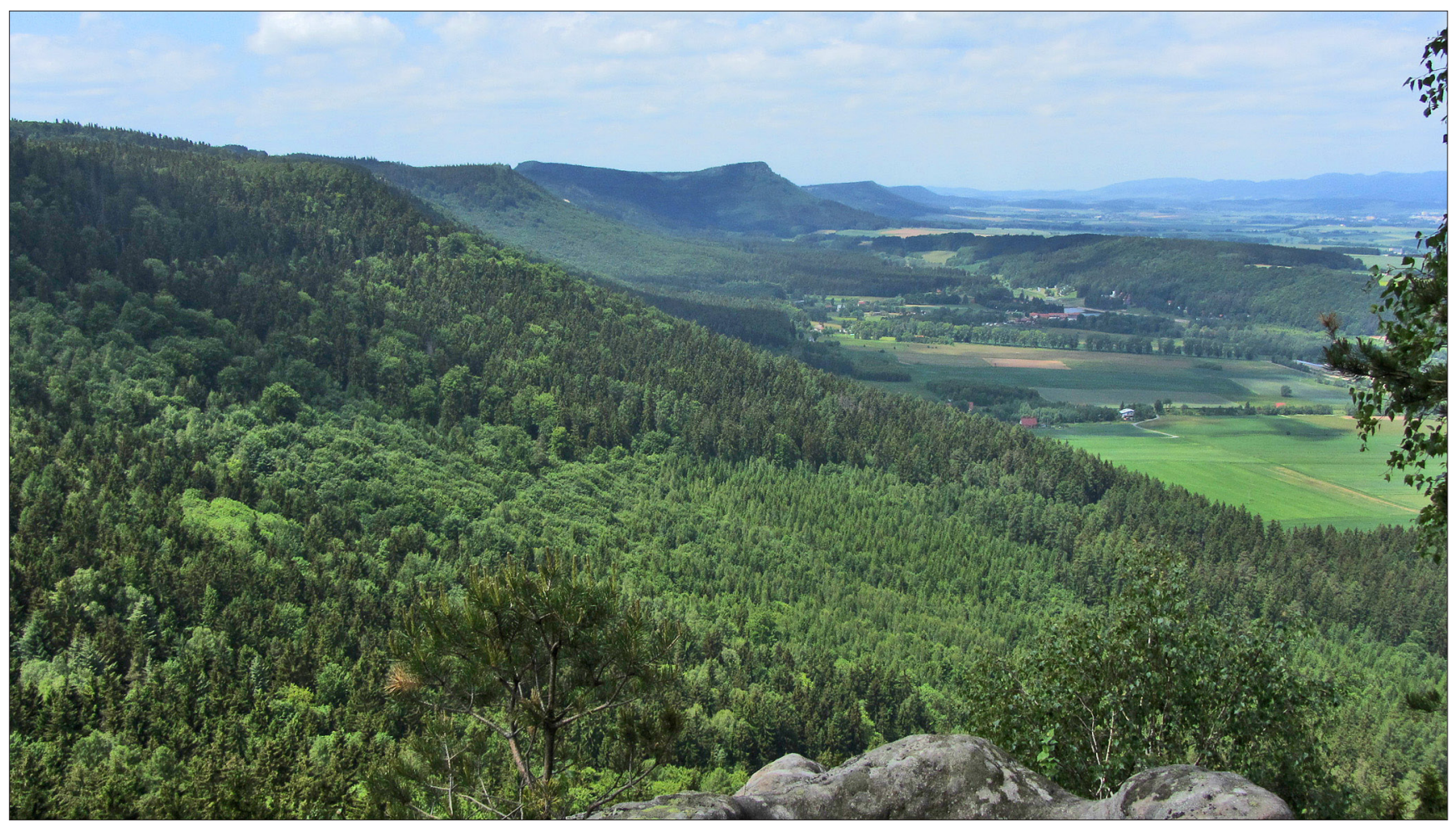

Fig. 6. The northern edge of the middle plateau of the Stołowe Mts., photo M. Rogowski • Północna krawędź środkowego poziomu Gór Stołowych, fot. M. Rogowski

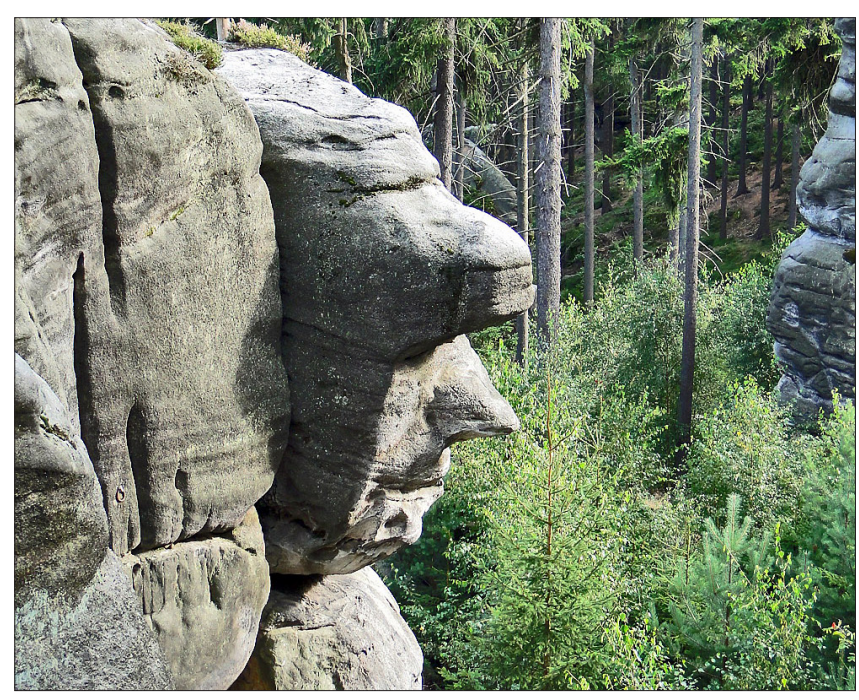

Fig. 7. Devil's Rock on red sandstone in the Stołowe Mts., photo M. Rogowski • Czartowskie Skały zbudowane z czerwonego piaskowca w Górach Stołowych, fot. M. Rogowski

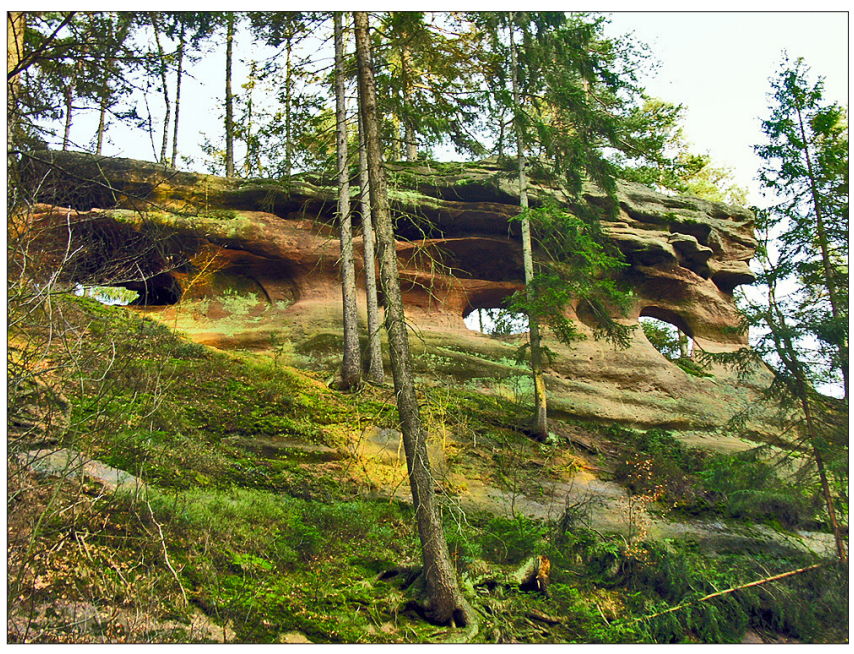

Fig. 8. Traitor Rock in the Ostaš Massif - one of the geosites in the Sudetic Geostrada, photo M. Rogowski • Skała Zdrajca w masywie Ostaš - jedno z geostanowisk Geostrady Sudeckiej, fot. M. Rogowski 

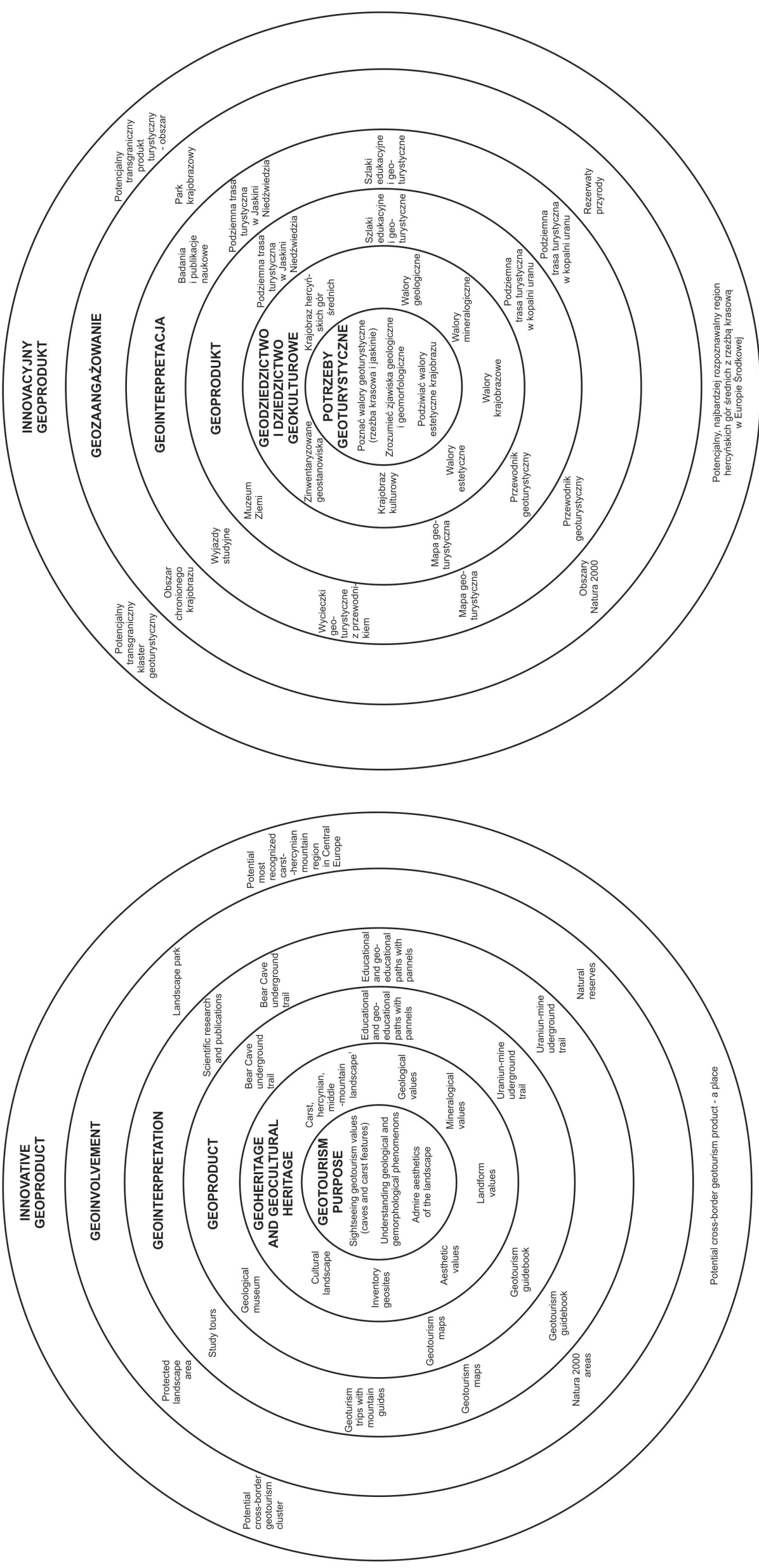

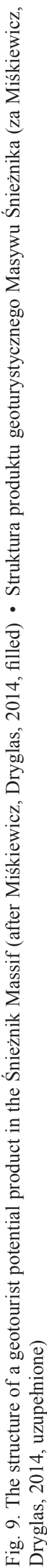




\section{The Śnieżnik Massif}

Karst geotouristic values of the Śnieżnik Massif are unique and valuable. The geotourism attraction was described by Koszela and Marek (2013). Staszek (2014) and focused on the Kleśnica Valley, where 12 geosites were marked. Many valuable geological objects, as well as remnants of ancient mining, constituting valuable cultural-historical legacy are located in the area of the discussed valley. These objects include the Bear Cave, marble quarry, Marianna Spring, spoilheap, Museum of the Earth, mine of uranium and "Gracious Stone" lime kiln (Koszela, Marek, 2013). The aesthetic values were categorized by Wyrzykowski et al. (1991) as a first class landscape with greatest visual values including relief and land cover.

The geotourism infrastructure composes of two underground trails in Niedźwiedzia cave and Uranium Mine in Kletno, Earth geological museum in Kletno, educational path Karst around Niedźwiedzia cave and 4 other geological and geomorphological objects in the Polish and Czech parts. There is a Naučná stezka Králický Sněžník, Kletno - Mt. Śnieżnik, Puchaczówka Pass - Mt. Śnieżnik and Path around Stronie Śląskie (www 6). Finally, there is a geological-tourist map of Śnieżnik Massif. All of these activities contribute to developing a karst cross-border geotouristic region. Unique karst values, existing infrastructure and activity of local government of Stronie Śląskie and Staré Město pod Sněžnikem create a friendly atmosphere in the touristic product of this region (Figs 9, 10).

\section{The Watbrzych Geotourist Area}

This area is composed of the Kamienne Mts., the Wałbrzyskie Mts., the Sowie Mts., the Wałbrzyskie Foothills, the Kamienna Góra Basin and was presented by Ihnatowicz et al. (2011). These authors made an inventory of 149 geotopes located in the Walbrzych Geotourist Area and described the results of valorization. These geotopes have been selected and evaluated. They represent 6 geological themes sedimentology, volcanism, metamorphism, geomorphology, hydrogeology, quaternary geology.

These themes show the most attractive types of the geotouristic offer:

- volcanism phenomena and landforms in the Suche and the Wałbrzyskie Mts.,

- hydrogeological phenomena - gorges and ravines in the Wałbrzych Geotourist Area

- a coal deposit and mines in the Wałbrzyskie Mts.

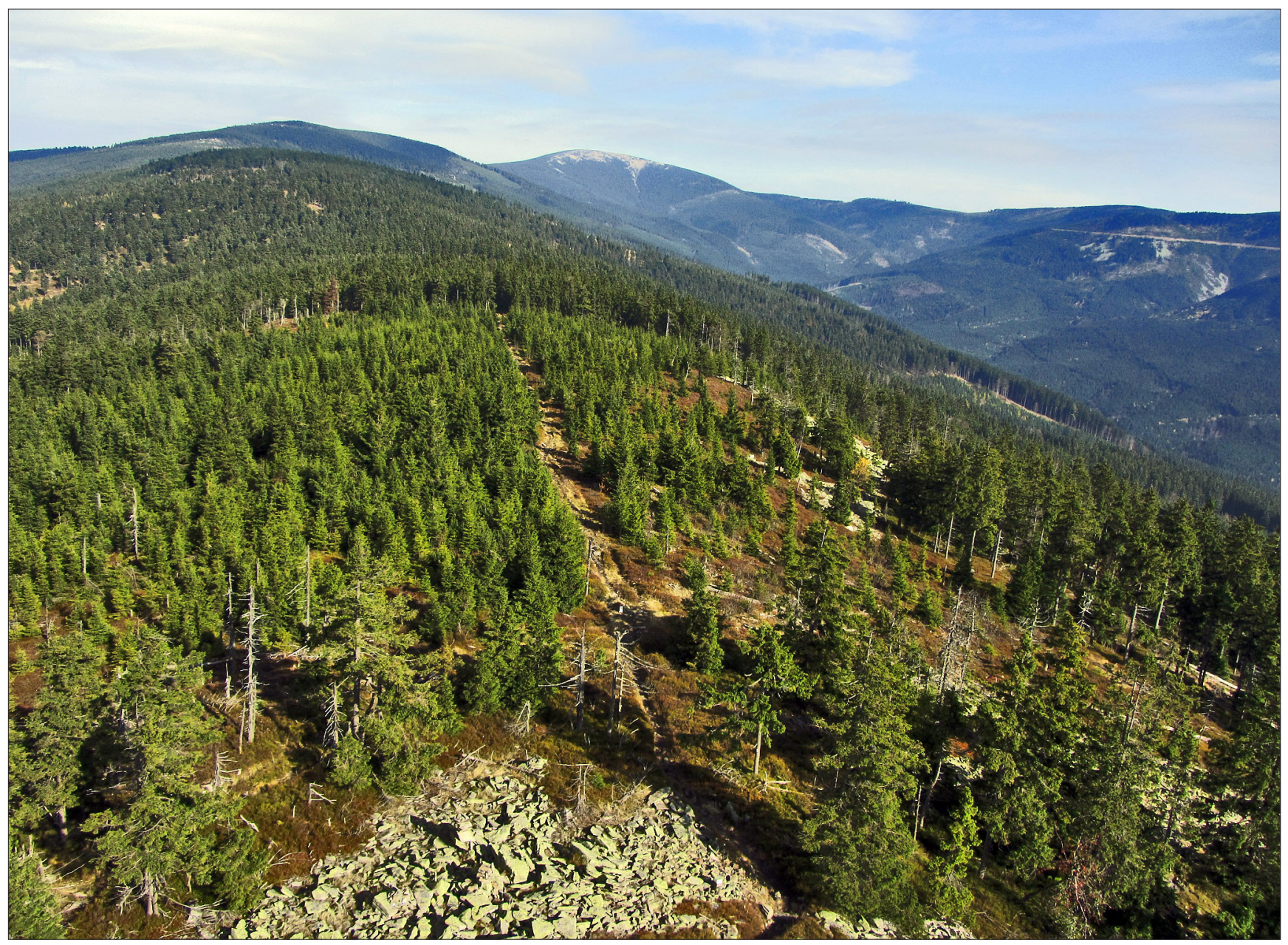

Fig. 10. View from Klepac (Three Seas Summit) towards the Mt. Śnieżnik. The peak is covered by gneiss rubble, photo M. Rogowski • Widok z Klepacza (Trójmorskiego Wierchu) w kierunku Śnieżnika. Szczyt pokryty rumowiskiem gnejsowym, fot. M. Rogowski 

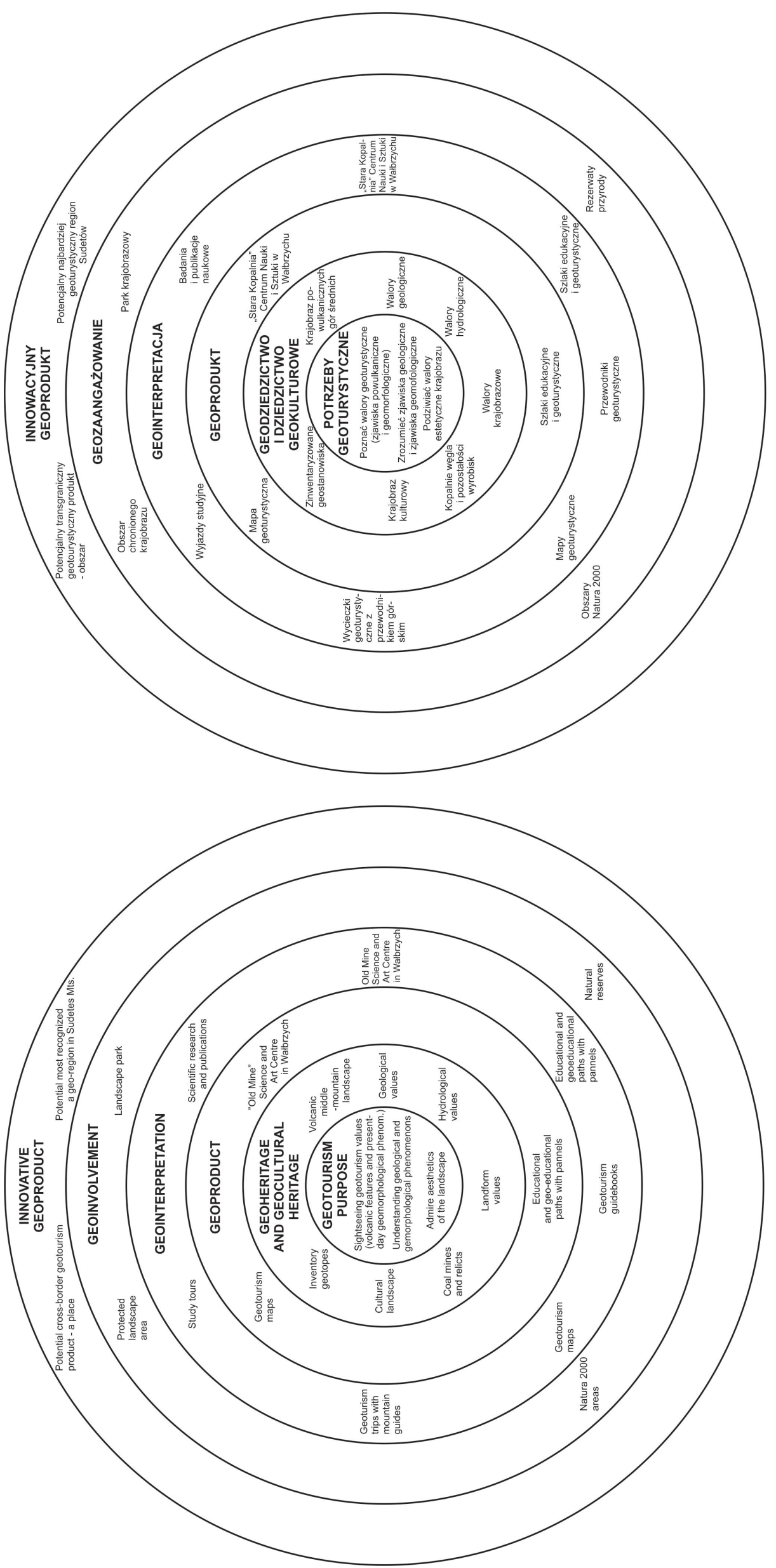

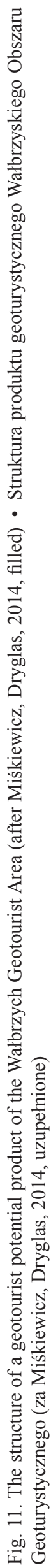




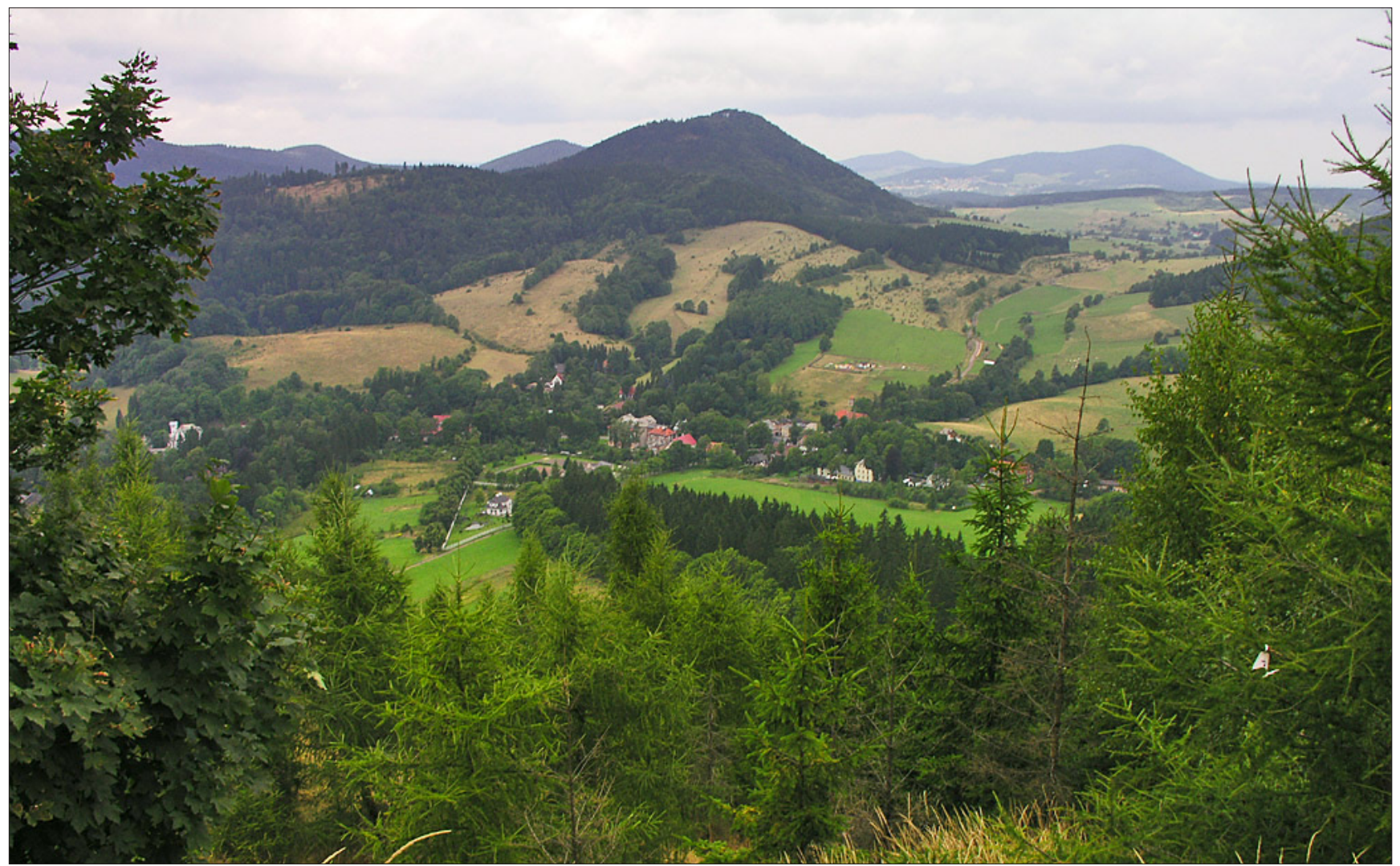

Fig. 12. Stożek Wielki - one of the steepest peaks in the Wałbrzych Geotourist Area, photo M. Rogowski • Stożek Wielki - jeden z najbardziej z najbardziej stromych szczytów w Wałbrzyskim Obszarze Geoturystycznym, fot. M. Rogowski

The aesthetic values were categorized by Wyrzykowski et al. (1991) as a first class landscape with greatest visual values including relief and land cover.

Based on the results of the valorization of geotopes, analyses of geology and geomorphology of the area, as well as evaluation of land development, the seven geotourist sub-areas (so-called domains) have been differentiated. The results of the geotopes inventory and valorization indicate a possibility to propose a new geotouristic area in the examined region and name it the Wałbrzych Geotourist Area (Ihnatowicz et al., 2011). These authors suggested further means of geotouristic development - an ecomuseum, educational pedestrian paths and roads. The Wałbrzych Geotourist Area possess a great potential in geotouristic development. At present, this is a region without any development of geotourism (Fig. 11, 12).

\section{A geotouristic product - a trail}

\section{Sudetes Georoute}

The international project Sudetes Georoute was created by the Lower Silesia Branch of the Polish Geological Institute .- National Research Institute and Czech Geological Survey in 2013. It was founded by the Operational Programme for the Czech Republic - Republic of Poland Cross-Border Cooperation 2007-2013. The project is aimed at the creation of an attractive geotouristic route, $600 \mathrm{~km}$ long, within cross-border areas of Poland and Czech Republic (Cwojdziński et al. 2011). The results of geological and landscape studies along this route was presented in three parts: West Sudetic Geostrada (Łodziński et al., 2009), Central Sudetic Geostrada (Bartuś et al., 2009) and Eastern Sudetic Geostrada (Słomka et al., 2009). The project provided a geological-tourist guidebook, 21 information boards, 21 information leaflets and a website www.geostrada.eu (www 7). This route measures over $600 \mathrm{~km}$ and has 300 viewing points. It is a cross-border geotourist project - a trail according to Kaczmarek et al. (2010), constructed of a series of places or sites bound by a theme and forming a route. In the pyramid of tourist products, the route represents the highest level of integration. This group includes products that require organizational integration (unification of elementary products) and have particular localization in the geographic space (Stasiak, 2006). The Sudetes Georoute idea is a geotourism subject with geological and geomorphological values, with the possibility to visit by car, bike and occasionally on foot and with educational, scientific and aesthetic motives of tourist activity.

For the sake of specialist language used in the guidebook, the Sudetes Georoute is actually dedicated mainly to geologists, geomorphologists and well prepared Sudetes fans. It is certain, that an offer should be prepared for awider group of geotourists and landscape tourists. A lack of analysis of the demand for the Sudetes Georoute and geotourism in the Sudetes Mts. leads to the lack of a geotourist offer (Fig. 13). 


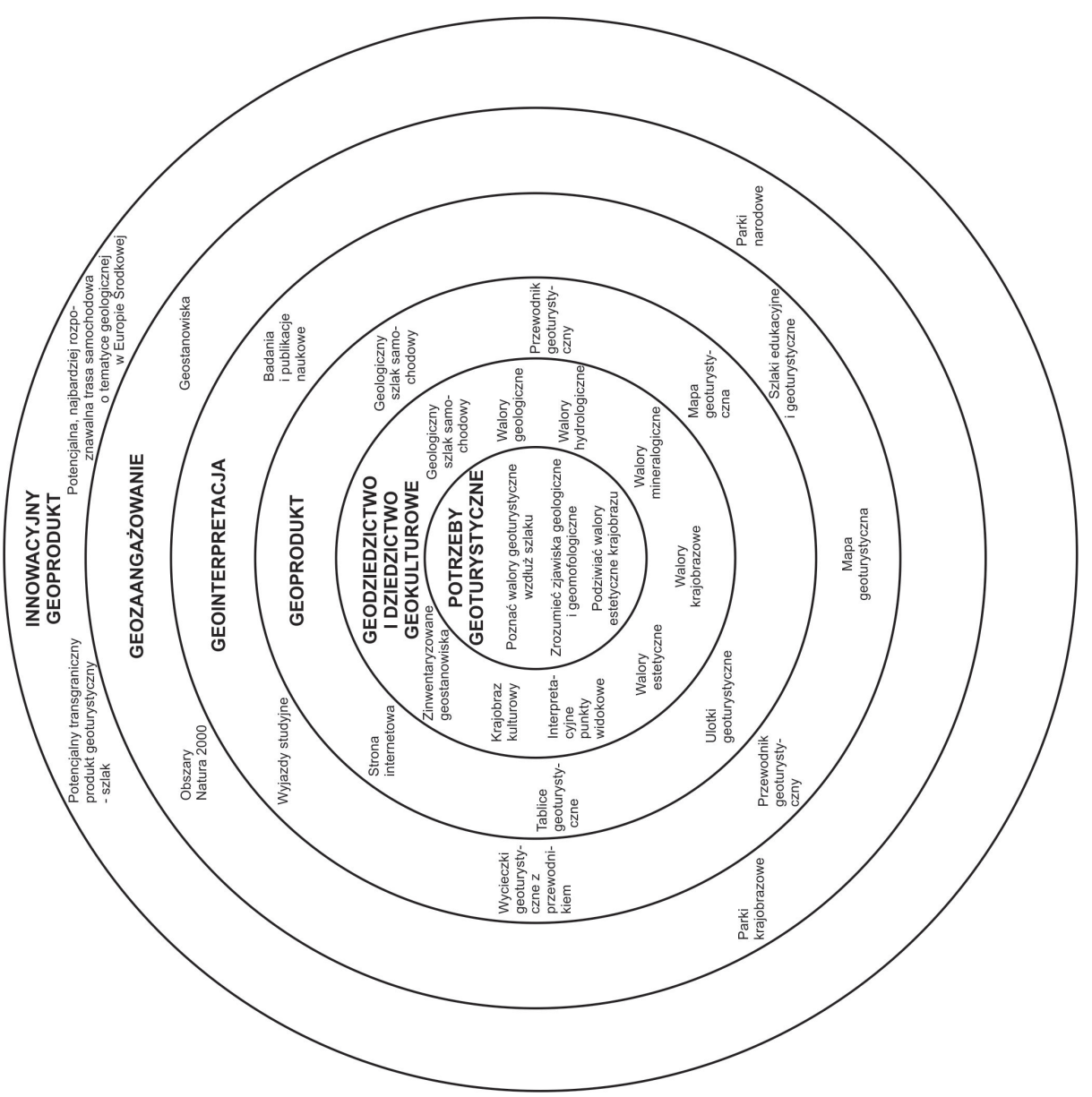




\section{Potential product of the trail of the mineral spring}

Since a few centuries ago, several dozen health resorts in the Sudetes Mts. are in operation. A the base of their activity, various mineral springs, one containing essential elements of inanimate nature, are distinguished (www 8). They belong to a very important group of geotouristic objects. For many years, according to Marszałek et al. (2008), spring water has been used for drinking purposes, and also very often as medicinal water, with regard to its specific chemical composition and physicalor pharmaco-dynamic properties. Health resorts and spas have been found in the place of the occurrence of mineral springs. In the Sudetes Mts., well-known springs of mineral and thermal water occur, recognized as medicinal water.

The tourist product of a health resort consists of elements, on the one hand, delivered by the destination and on the other hand, by subjects influencing formation, development and management of the health resort. The elements of the touristic product of a health resort are dependent on the activities undertaken by public, private and non-profit sectors. Among the groups responsible for shaping the tourist products of a health resort, local society and tourists or patients should be mentioned (Dryglas, 2012).

At present, 9 health resorts on the Polish part and 8 on the Czech part exist in the Sudetes Mts (www 8; www 9). Every resort has various offers, based on mineral and thermal spring and peloids. Cooperation between these resorts in creating a coherent offer, promotion and brand has begun some years ago. Joint action of every Sudetes health resort strengthens their position on the European touristic market.

\section{Potential product of underground touristic routes}

Based on the distribution of natural resources, mining sites and their potential as well as actual use in Geotourism, Nita and Myga-Piątek (2014) selected 20 actual and potential geotouristic regions in Poland. These regions were divided into three basic categories based on their attractiveness. Lower Silesia, especially the Sudetes Mts., is a first class region with international importance and several large exploitation and post-exploitation objects.

Currently 13 underground tourist routes located in the Sudetes Mts. will make a touristic product - a trail. This consists of 5 caves and 8 mining objects. There are Niedźwiedzia cave, Radochowska cave, Bozkovské dolomitové cave, Na Pomezí cave, Na Špičáku cave gold mines in Złotoryja and Złoty Stok, coal mines in Nowa Ruda, Wałbrzych with Old Mine Science and Art Centre (Stara Kopalnia - Centrum Nauki i Sztuki), The Bohumir Mine in Žacléř, ore mine in Obří Dul under Śnieżka Mt. and uranium mines in Kletno and Kowary (www 10). The caves in the Czech Republic are managed by the Caves Administration of the Czech Republic (Správa jeskyní České republiky) with protection, management and promotion activities created for the brand. Every object will be a part of an underground route, with a common marking strategy and coherent image. The product infrastructure is composed of existing underground marked tourist trails, guided services, educational panels and storytelling. Niedźwiedzia Cave, gold mine in Złoty Stok, coal mine in Nowa Ruda and uranium mine in Kowary and Kletno represent the most developed tourist offers, and according to Góralewicz-Drozdowska et al. (2013), have the richest storytelling in Lower Silesia.

Additionally, some authors take notice of the geotouristic potential of the military complex constructed during World War II. The possibilities of geotouristic development on the example of Osówka complex, presented by Stach (2014), emphasize two values: geological - associated with precious objects of inanimate nature, and historical. In the Owl Mts., there are seven underground facilities under the Riese code name for the construction project of Nazi Germany. At present, three objects are tourist attractions with underground routes related to military tourism. But according to their geological features, this complex has also potential geotouristic values.

Thanks to most touristic recognized objects in association with the caves in the Czech Republic, a leading function of cross-border geotouristic product will be defined. Cooperation between all underground trail management will produce promotional campaigns, tourist information, common tickets, special offers, sightseeing tours and organization of events.

Furthermore, the product of the underground touristic routes can be divided into three sub-products:

- "Sudetes caves" on Polish and Czech areas,

- "Sudetes mines and tunnels" with plenty of mineral resources, aimed at industrial tourists,

- "Military complexes in the Sudety Mts.", aimed at military tourists, with the Czechoslovakian defense fortifications from 1935-1938 named Benes Line.

\section{Potential product of geotouristic pedestrian trails}

In the first geotouristic region, 27 educational paths and trails exist. In other regions, there are more than ten other educational trails presenting geotouristic values. These trails are equipped with educational panels and enable tourists to make individual trips. The complex management of these trails has made it possible to publish guidebooks, brochures and create phone application and multimedia guides. Divided into 3 networks, geotouristic paths make a product in:

- 13 educational paths in Karkonosze Mts. managed by the staff of Karkonosze National Park, forest district and 
Karpacz, Szklarska Poręba, Piechowice towns, these paths are a part of the infrastructure of a product - a place; some of them have its own names -Giant Mountains Glacial Heritage Educational Path (Dziedzictwo Polodowcowe Karkonoszy), Geotourist path in the Eastern Karkonosze (Ścieżka geoturystyczna we wschodnich Karkonoszach), Nature Path Around the Cirques of the Large and Small ponds (Ścieżka przyrodnicza wokół kotłów Małego i Wielkiego Stawu); there are also published tourist brochures about the mentioned trails;

- 11 educational paths and 2 tourist trails in the Land of Extinct Volcanoes managed by the Kaczawskie Partnership and PTTK; typical geotourist trails are: Trail of Extinct Volcanoes (Szlak Wygasłych Wulkanów) and Edge Trail (Szlak Brzeżny);

- 9 educational paths in Stołowe Mts. managed by Stołowe National Park, partnership Broumovsko and NPR Adršpašsko-Teplické skály.

Thanks to national and landscape park cooperation, geotouristic pedestrian trails will form a coherent trail network in the Sudetes Mts.

\section{Simple geotouristic products}

Most simple geotouristic products are a part of complex ones. Therefore in this part of the text, they will be only mentioned. These are product - a service, an entity and an object according to Dryglas and Miśkiewicz (2014).

Geotouristic product - a service is represented by the Karkonosze National Park geotouristic trips. Games on geotouristic pedestrian trails Nature Path Around the Cirques of the Large and Small ponds, Geotourist path in the Eastern Karkonosze, Glacial heritage of Karkonosze" will serve as terrain lesson usage. Another service product is run by The Sudecka Education Centre in Dobków (Sudecka Zagroda Edukacyjna). It includes searching for minerals: agates, amethyst and quartz in nearby quarry and geological workshops (www 11).

Geotouristic product - an entity - can be perceived in Niedźwiedzia cave, gold mine in Złoty Stok, coal mine in Nowa Ruda and uranium mine in Kowary and Kletno. The offer of these objects composes of forms of live interpretation - spoken stories, performed or broadcasted interpretation and workshops, as well as different forms of written and visual interpretation (Góralewicz-Drozdowska et al., 2013). Other products are: Centre of Ecological Education in the Karkonosze National Park (Centrum Edukacji Ekologicznej Karkonoskiego Parku Narodowego) in Szklarska Poręba, The Sudecka Education Centre in Dobków (Sudecka Zagroda Edukacyjna) and permanent ecological expositions in Vrchlabi. Earth Geological Museum in Kletno and Minerals Museum in Szklarska Poręba. They present geotouristic resources of this land. Additionally, they offer mineral workshops and rock recognition.
Geotouristic product - an object- includes various printed materials characterizing geotourist values in the Sudetes Mts. There are 10 books: Path of Rock Landform in Stołowe Mts. (Pulinowa, 2000), Sudetes Mts. geotourism guidebook (Cwojdziński, Kozdrój, 2007), Geotourism guidebook in the Karkonosze National Park (Knapik, 2008), Guidebook of geotourist paths in the eastern Karkonosze (Knapik, 2011a), Minerals of the Polish Karkonosze (Knapik, 2011b), Geoattractions of the Stołowe Mts. National Park (Wojewoda, 2011), Geoattractions of Radków (Wojewoda ed., 2013), geological-tourist guidebook Sudetes Georoute (Gawlikowska ed., 2013), photography album Geotourism attractions of The Land of Extinct Volcanoes (Migoń, 2014b), Kaczawskie Mts and Foothills, The Land of Extinct Volcanoes, guidebook with maps (Migoń, 2014c). There are 6 maps: Śnieżnik Massif - geological-tourist map (Gawlikowska, Opletal, 1997), Stołowe Mts. geological-tourist map (Čech, Gawlikowska, 1999), Atlas Geodiversity and geotouristic values of Karkonosze National Park (2011), map in the geological-tourist guidebook Sudetes Georoute (Gawlikowska ed., 2013), Geoatraction map of Stołowe Mts. and Broumovske Steny (Wojewoda, 2013), Kaczawskie Mts and Upland, The Land of Extinct Volcanoes, geotouristic map (Migoń, 2014d).

\section{Summary}

Year after year, the touristic supply of the Sudetes Mts. region expands. The geotouristic offer grows as well. Thanks to inventory, evaluation and recognition of the needs of geotourists, a good offer can be prepared in cooperation with the local community, creating a brand touristic product. Subsequently, products can develop into a touristic network and cluster. According to Roberts (2000), natural resources provided small touristic companies with a clustering incentive around geographic icons such as natural health spas or a national parks. Cluster research indicates that industrial players tend to concentrate their activities in certain locations, demonstrating that the tourism industry has the potential to achieve positive economic outcomes through clustering. In the European and American touristic market, there are various cluster initiatives which bring socio-economic profits. One of them is the Lake Tahoe Basin Prosperity Plan Cluster Path for a Sustainable Economy. The main aim of the touristic clusters is to build partnership between local business, educational and research units, local authorities, and representatives of local governments. All members including those from private and public sectors, work together for the most effective use of the tourist potential of the local destination (Melisidou et al., 2014). There is a big chance for the firstrate Sudetes subregions, with the best geotouristic values, to become a clustering initiative. This can create a cross-border brand of a geotouristic product of the Sudetes Mts, utilizing the subregions (Fig. 14). 


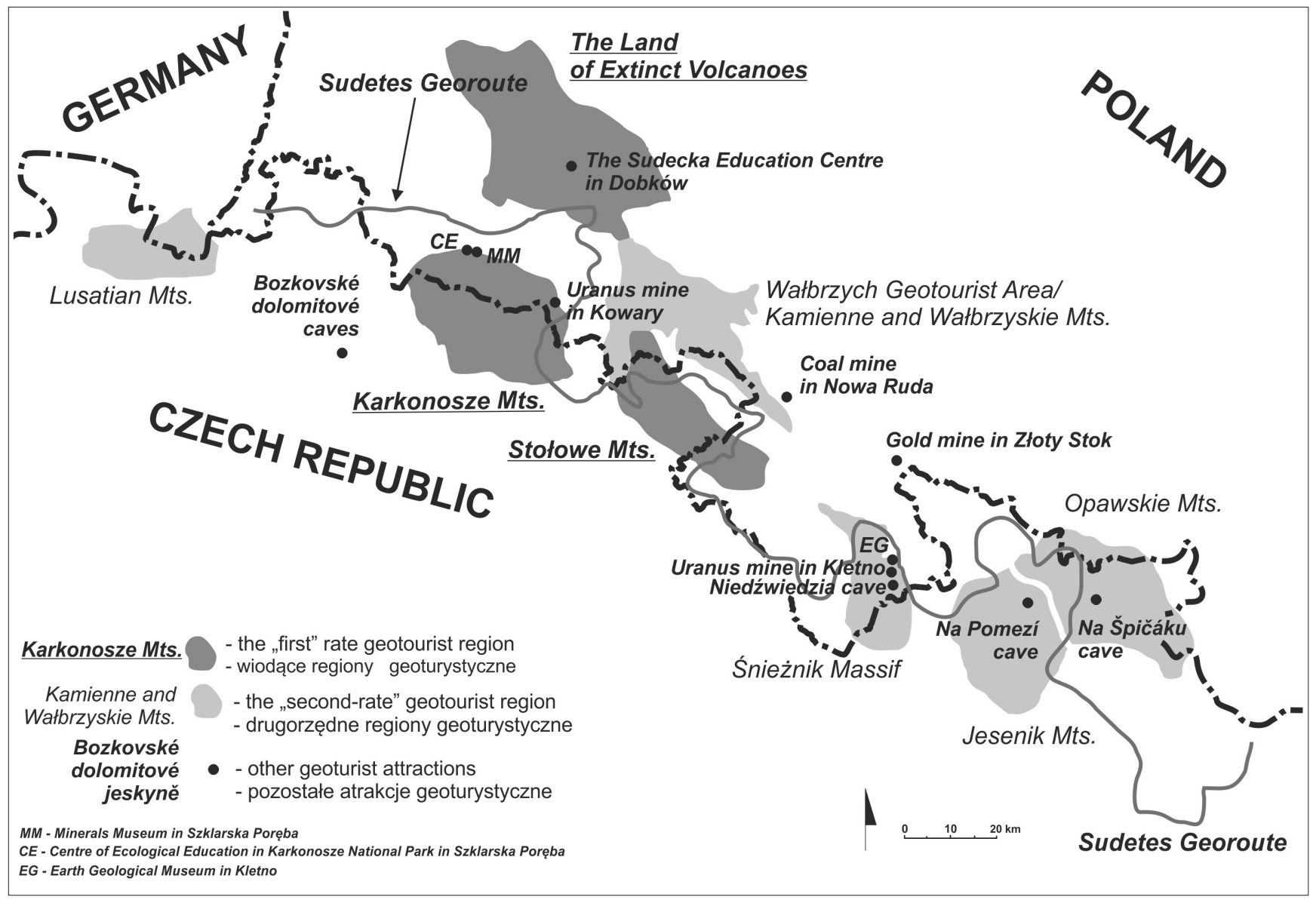

Fig. 14. A geotourist potential product of the Sudetes Mts. Subregions (source: Rogowski, 2014) • Potencjalne produkty geoturystyczne subregionów Sudetów (źródło: Rogowski, 2014)

\section{Streszczenie}

\section{Potencjał regionu Sudetów} w kreowaniu produktów geoturystycznych

\section{Mateusz Rogowski}

\section{Wprowadzenie}

Współcześnie coraz częściej gospodarczy rozwój regionu rozpatrywany jest przez pryzmat turystyki. Sudety mają duży i różnorodny potencjał turystyczny, a rozwój geoturystyki związany jest z budową geologiczną i rzeźbą terenu. Potencjał ten może zostać wykorzystany w kreowaniu produktów geoturystycznych. W przypadku takich regionów podejmowane są coraz bardziej widoczne inicjatywy, którymi są m.in. lokalne grupy działania, stowarzyszenia, ośrodki edukacyjne, geoparki, szlaki dydaktyczne oraz opracowania krajoznawcze. Dobrze funkcjonujące działania mogą być postrzegane przez pryzmat specyficznego produktu geoturystycznego. Celem artykułu jest przedstawienie potencjału regionu Sudetów służącego do kreowania produktów geoturystycznych oraz podział produktów na poszczególne kategorie w danych regionach. Natomiast dzięki takiej ofercie można wykreować transgraniczny, sieciowy produkt turystyczny, rozumiany jako ,zbiór użyteczności związanych z podróżami turystycznymi, czyli dostępne na rynku dobra i usługi turystyczne umożliwiające ich planowanie, odbywanie, przeżywanie oraz gromadzenie doświadczeń z nimi związanych" (Kaczmarek et al., 2010). Wykorzystując hierarchiczny układ materialnych i niematerialnych kategorii geoproduktu (Dryglas, Miśkiewicz, 2014), na obszarze Sudetów można wyróżnić pięć kategorii produktów geoturystycznych (Tab.1):

- miejsce - regiony wyróżniające się walorami geoturystycznymi,

- szlak - szlaki geoedukacyjne i geoturystyczna trasa samochodowa,

- usługa - wycieczki geoturystyczne,

- obiekt - muzea i centrum geoedukacyjne,

- rzecz - przewodnik i mapy.

\section{Potencjal geoturystyczny Sudetów}

Zestawienie istniejących i potencjalnych geoproduktów Sudetów zostało poprzedzone inwentaryzacją istniejących 
opracowań oraz atrakcji geoturystycznych. W związku z tym można wyróżnić dwa typy regionów w aspekcie potencjału geoturystycznego:

- „regiony wiodące”, charakteryzujące najcenniejszymi walorami geoturystycznymi z najbardziej rozwiniętą infrastrukturą (Karkonosze, Góry i Pogórze Kaczawskie, Góry Stołowe);

- „regiony drugorzędne” z wysokim potencjałem geoturystycznym, który jest jeszcze słabo rozpoznany (Góry Kamienne, Góry Wałbrzyskie, Masyw Śnieżnika, Wysoki Jesenik, Góry Opawskie i Góry Łużyckie) (Rogowski, 2014).

Do głównych walorów geoturystycznych Sudetów można zaliczyć:

- górską rzeźbą polodowcową,

- pozostałości działalności wulkanicznej,

- formacje i labirynty skalne,

- zjawiska krasowe, np. Jaskinia Niedźwiedzia,

- wąwozy rzeczne Nysy Kłodzkiej, Pełcznicy, Bobru,

- dawne sztolnie i kopalnie surowców mineralnych,

- cykliczne wydarzenia: Lwóweckie Lato Agatowe w Lwówku Śląskim, Międzynarodowe Mistrzostwa Polski w Płukaniu Złota w Złotoryi.

\section{Produkt geoturystyczny - obszar Karkonosze}

Karkonosze, jako najwyższy i najrozleglejszy region Sudetów, charakteryzują się bardzo cennymi walorami geoturystycznymi, na które składają się walory geologiczne, mineralogiczne i geomorfologiczne, pozostałości sztolni i krajobraz kulturowy. Zostały one opisane i ocenione w opracowaniach autorstwa R. Knapika et. al. (2011) oraz M. Rogowskiego et al., (2013), w których do najcenniejszych zaliczono m.in. Mały Śnieżny Kocioł, Wielki Śnieżny Kocioł, skały Pielgrzymy, kocioł Małego Stawu i Śnieżkę. Infrastrukturę geoturystyczną tworzą centra i szlaki edukacyjne, przewodniki i mapy goturystyczne. Pracownicy Karkonoskiego Parku Narodowego organizują wycieczki geoturystyczne i warsztaty terenowe. W przyszłości obszar ten może się stać transgranicznym produktem geoturystycznym i najbardziej rozpoznawalnym obszarem górskim wieku hercyńskiego w Europie, dla którego można zaproponować nazwę „Polodowcowa Kraina Liczyrzepy” (Fig. 1, 2).

\section{Góry i Pogórze Kaczawskie}

Góry i Pogórze Kaczawskie leżące w Sudetach Zachodnich cechują się wysoką georóżnorodnością obejmującą walory geologiczne, mineralogiczne i geomorfologiczne związane z wulkanizmem, pozostałości kopalni złota i kamieniołomów oraz krajobraz kulturowy. Charakterystycznym elementem krajobrazu są wzgórza stanowiące neki wulkaniczne, takie jak Ostrzyca czy Grodziec oraz skalne słupy zastygłej lawy. Walory geoturystyczne zostały opisane w pracach (Pijet-Migoń, Migoń, 2009) i (Migoń, Pijet-Migoń, 2010) oraz (Mianowicz,
Brzozowska, 2009) i (Różycka, 2014). Ponadto Cedro et al. (2009) dokonali oceny geostanowisk, wśród których do najcenniejszych należą: Wilcza Góra, Organy Wielisławskie i Wąwóz Myśliborski. Do głównych atrakcji można zaliczyć Kopalnię Złota „Aurelia”, Muzeum Złota w Złotoryi, Skansen Górniczo-Hutniczy w Leszczynie i Lwóweckie Lato Agatowe oraz Międzynarodowe Mistrzostwa Polski w Płukaniu Złota. $\mathrm{Na}$ infrastrukturę składają się szlaki edukacyjne i turystyczne. Opublikowano także przewodnik, mapę i album geoturystyczny. Od 2004 roku działa w tym obszarze Lokalna Grupa Działania Partnerstwo Kaczawskie kreująca nazwę regionu „Kraina Wygasłych Wulkanów”. Najważniejszą inicjatywną jest Sudecka Zagroda Edukacyjna, przybliżająca zagadnienia wulkanizmu, oferująca warsztaty i wycieczki o tematyce geoturystycznej. Ponadto istniejące Ekomuzeum Rzemiosła w Dobkowie promuje warsztaty artystyczne, zachowując krajobraz kulturowy. Dzięki temu potencjał geoturystyczny tego obszaru stanowi podstawę rozwoju oferty o charakterze międzynarodowym dla różnych grup turystów. Kraina Wygasłych Wulkanów może stać się produktem geoturystycznym, stając się w przyszłości najbardziej rozpoznawalnym regionem z rzeźbą powulkaniczną w Europie Środkowej (Fig. 3, 4).

\section{Góry Stołowe}

Góry Stołowe to jeden z najpopularniejszych regionów turystycznych Sudetów znajdujący się na pograniczu polsko-czeskim, mający unikatową budowę płytową składającą się z trzech poziomów: najwyższego, środkowego i najniższego. Walorami geoturystycznymi są piaskowcowe formacje i labirynty skalne, opisane w przewodnikach geoturystycznych (Wojewoda, 2011, Wojewoda ed., 2013) i na mapach geologiczno-turystycznych (Čech, Gawlikowska, 1999; Wojewoda, 2013). Po stronie czeskiej realizowana jest lokalna inicjatywa „Geopark Broumovsko”, w ramach której zinwentaryzowano i opisano 44 geostanowiska. Na infrastrukturę składa się dziewięć szlaków edukacyjnych i centrum edukacyjne „Geopark Vnitrosudetská pánev Vižňov”, a ponadto powstał przewodnik geoturystyczny. Góry Stołowe tworzą potencjalny, transgraniczny produkt geoturystyczny o charakterze obszaru. Unikatowy krajobraz którego rzeźba jest odzwierciedleniem płytowej budowy geologicznej związanej z osadowym pochodzeniem tworzacych je skał (piaskowców) może stać się jednym z najbardziej rozpoznawalnych w Europie Środkowej (Fig. 5, 6, 7, 8).

\section{Masyw Śnieżnika}

Masyw Śnieżnika znajduje się w Sudetach Wschodnich. Jego walory geoturystyczne zostały scharakteryzowane przez Koszelę i Marka (2013), a ponadto Staszek (2014) wyróżnił 12 geostanowisk w Dolinie Kleśnicy. Na walory geoturystyczne składają się zjawiska krasowe, pozostałości kamieniołomów i sztolni oraz krajobraz kulturowy, a głównym atrakcjami są Jaskinia Niedźwiedzia i Sztolnia Uranowa z podziemnymi trasami turystycznymi, Muzeum Ziemi oraz Źródło Marianny (Koszela, Marek, 2013). Całość tych 
atrakcji została oznaczona na geologiczno-turystycznej mapie regionu. Inwestycje i inicjatywy geoturystyczne mają poparcie w lokalnym samorządzie i mogą być postrzegane w kontekście potencjalnego transgranicznego produktu geoturystycznego o charakterze obszaru (Fig. 9, 10).

\section{Walbrzyski Obszar Geoturystyczny}

Wałbrzyski Obszar Geoturystyczny zdefiniowany w ten sposób przez Ihnatowicza et al. (2011) obejmuje swoim zasięgiem obszar Sudetów Środkowych, z Górami Kamiennymi, Górami Wałbrzyskimi i Pogórzem Wałbrzyskim, Górami Sowimi oraz Kotliną Kamiennogórską. Na tym terenie wyróżniono, opisano i oceniono 149 geotopów, reprezentujących sześć zagadnień dotyczących m.in. zjawisk wulkanicznych, hydrogeologicznych i terenów górniczych. W wyniku dokonanej oceny wyróżniono podobszary geoturystyczne (domeny) związane z charakterem walorów, zaproponowano utworzenie ekomuzeum, szlaków edukacyjnych i trasy samochodowej. Dzięki temu Wałbrzyski Obszar Geoturystyczny można wykreować jako produkt o charakterze obszaru (Fig. 11, 12).

\section{Produkt geoturystyczny - szlak Geostrada Sudecka}

Geostrada Sudecka to projekt międzynarodowej, geoturystycznej trasy samochodowej, utworzonej przez polską i czeską służbę geologiczną. Została ona opisana przez Cwojdzińskiego et al. (2011), a jej walory scharakteryzowano $\mathrm{w}$ odrębnych pracach $\mathrm{z}$ podziałem na odcinki: zachodni (Łodziński et al., 2009), centralny (Bartuś et al., 2009) i wschodni (Słomka et al., 2009). Projekt obejmuje geologiczno-turystyczny przewodnik, 21 broszur i tablic edukacyjnych oraz domenę internetową www.geostrada.eu (www 1). Trasa ma 600 km długości i 300 punktów obserwacyjnych i jest postrzegana jako produkt turystyczny - szlak opisany przez Kaczmarka et al. (2010). Jest on spójny i przestrzennie zdeterminowany.Szlak jest dobrze zorganizowany i może być pokonywany samochodem, rowerem oraz pieszo, w celu realizacji celów edukacyjnych, naukowych, estetycznych oraz aktywnych. Z uwagi na specjalistyczny, typowo naukowy język użyty w przewodniku, Geostrada Sudecka przeznaczona jest głównie dla geologów, geomorfologów czy entuzjastów tego obszaru. W tym przypadku powinna zostać dodatkowo utworzono oferta dla szerszego grona odbiorów (Fig. 13).

\section{Potencjalne szlaki geoturystyczne}

Ze względu na specyficzne walory geoturystyczne Sudetów i ich zagospodarowanie można zaproponować trzy potencjalne szlaki o charakterze transregionalnym związane z wodami mineralnymi, trasami podziemnymi oraz edukacyjnymi.

Szlak wód mineralnych Sudetów nawiązuje do dziewięciu polskich i ośmiu czeskich ośrodków uzdrowiskowych tego obszaru, działających z wykorzystaniem naturalnych surowców leczniczych i cech klimatu. Produkt turystyczny uzdrowisk składa się z elementów bezpośrednich, którymi są surowce, oraz podmiotów kształtujących ofertę zdrowotną. Ścisła współpraca pomiędzy uzdrowiskami powinna skutkować utworzeniem spójnej oferty, promocją i stworzeniem marki umożliwiającej konkurowanie na rynku europejskim.

Szlak podziemnych tras turystycznych Sudetów może zostać utworzony na bazie 13 tras umiejscowionych w pięciu jaskiniach i ośmiu kopalniach. Na ich infrastrukturę składa się oznakowanie i tablice edukacyjne, a ponadto ważnym elementem są usługi przewodnickie i wycieczki fabularyzowane. W wyniku przygotowania wspólnej, międzynarodowej strategii rozwoju trasy te mogą utworzyć spójną ofertę oraz stworzyć markę. Wykorzystując charakter walorów, można zaproponować trzy subprodukty obejmujące jaskinie sudeckie, kopalnie i sztolnie oraz pozostałości drugiej wojny światowej.

Szlak geoturystycznych tras edukacyjnych może objąć 27 oznakowanych tras pieszych przybliżających walory geoturystyczne. Dzięki wspólnej promocji instytucji zarządzających tymi trasami i przewodnikowi z kartami pracy trasy te mogą stanowić element spójnego produktu oferowanego na obszarze Karkonoszy w Górach i Pogórzu Kaczawskimi oraz w Górach Stołowych.

\section{Proste produkty geoturystyczne}

Na przykładzie Sudetów można także wyróżnić produkty turystyczne proste, takie jak obiekt, usługa i rzecz. W przypadku usługi należy wskazać wycieczki geoturystyczne i warsztaty stanowiące ofertę edukacyjną Karkonoskiego Parku Narodowego i Krainy Wygasłych Wulkanów. Na produkty turystyczne o charakterze obiektu składają się Jaskinia Niedźwiedzia oraz udostępnione sztolnie i kopalnie oferujące zwiedzanie fabularyzowane, warsztaty i różne formy wizualnej interpretacji dziedzictwa. Drugą grupą takich obiektów są Karkonoskie Centrum Edukacji Ekologicznej w Szklarskiej Porębie, Sudecka Zagroda Edukacyjna w Dobkowie, centrum edukacyjne w Vrchlabi, Muzeum Ziemi w Kletnie i Muzeum Mineralogiczne w Szklarskiej Porębie (Fig. 14). Do produktów turystycznych typu „rzecz” można zaliczyć materiały drukowane przybliżające walory geoturystyczne Sudetów, na które składa się 10 przewodników, sześć map i album fotograficzny.

\section{Podsumowanie}

Oferta geoturystyczna Sudetów rozwija się z roku na rok. Dzięki coraz większej liczbie prac naukowych opisujących i oceniających walory geoturystyczne oraz zaangażowaniu lokalnej społeczności w tworzenie zrównoważonej i ukierunkowanej oferty turystycznej możliwe będzie utworzenie klastra. Efektem jego działania będzie spójny wizerunek obszaru kojarzący się z określonymi walorami, kompleksowa i wysokiej jakości oferta geoturystyczna oraz międzynarodowa marka, co sprawi, że Sudety jako transgraniczny region będą mogły z sukcesem konkurować na arenie europejskiej. 


\section{References (Literatura)}

Andrejczuk W., 2010. Krajobraz a turystyka: aspekt konceptualny. Prace Komisji Krajobrazu Kulturowego, 14: 15-24.

Atlas. Georóżnorodność i geoturystyczne atrakcje Karkonoskiego Parku Narodowego i otuliny. 2011. Karkonoski Park Narodowy, Jelenia Góra.

Bartuś T., Mastej W., Łodziński M., 2009. Geotourist attractions of the Central Sudetic Geostrada. Geoturystyka, 19: 43-60.

Cedro B., Mianowicz K., Zawadzki D., 2009. Ocena walorów geoturystycznych stanowisk pochodzenia wulkanicznego Gór i Pogórza Kaczawskiego. In: Dudkowski M. (ed.), Problemy turystyki i rekreacji, t. 2: 25-35.

Cwojdziński S., Kozdrój W., 2007. Sudety - przewodnik geoturystyczny. Państwowy Instytut Geologiczny, Warszawa.

Cwojdziński S., Pacuła J., Stachowiak A., 2011. Geostrada Sudecka - nowa forma geoturystyki w Sudetach. Przeglad Geologiczny, 59: 510-535.

Čech S., Gawlikowska E., 1999. Góry Stołowe. Mapa geologiczno-turystyczna. Państwowy Instytut Geologiczny, Český Geologický Ústav. Warszawa-Praga.

Dryglas D., 2012. Spa and Wellness Tourism as a Spatially Determined Product of Health Resorts in Poland. Current Issues of Tourism Research, 2: 30-38.

Dryglas D., Miśkiewicz K., 2014. Construction of the geotourism product structure on the example of Poland. In: 14th GeoConferences on Ecology, Economics, Education and Legislation. International Multidisciplinary Scientific Geoconferences: 155-162.

Farsani N.T., Coelho C., Costa C., Carvalho C.N., 2012. Geoparks \& Geotourism. New Approaches to Sustainability for the 21st Century. Brown Walker Press.

Gawlikowska E. (ed.), 2013. Geostrada Sudecka. Przewodnik geologiczno-turystyczny. Państwowy Instytut Geologiczny, Česka Geologická Služba, Warszawa-Praga.

Gawlikowska E., Čech M., 1999. Góry Stotowe. Mapa geologiczno-turystyczna w skali 1:50 000. Państwowy Instytut Geologiczny, Český Geologický Ústav, Warszawa-Praga.

Gawlikowska E., Opletal M., 1997. Masyw Śnieżnika: mapa geologiczno-turystyczna w skali 1:50 000. Państwowy Instytut Geologiczny, Český Geologický Ústav, Warszawa-Praga.

Góralewicz-Drozdowska M., Gruszka I., Rogowski M., 2013. Storytelling at visitor attractions of Lower Silesia as a tourist product. In: Wyrzykowski J., Marak J. (eds), Tourism role in the regional economy, vol. IV. Regional tourism product - theory and practice: 227-237.

Gray M., 2004. Geodiversity - valuing and conserving abiotic nature. John Wiley \& Sons, The Atrium, Southern Gate, Chichester, West Sussex PO19 8SQ, England.

Hose T.A., 1995. Selling the story of Britain's Stone. Environmental Interpretation, 102: 16-17.

Ihnatowicz A., Koźma J., Wajsprych B., 2011. Wałbrzyski Obszar Geoturystyczny - inwentaryzacja geotopów dla potrzeb promocji geoturystyki. Przeglad Geologiczny, 59: 722-731.

Kaczmarek J., Stasiak A., Włodarczyk B., 2010. Produkt turystyczny. Pomyst, organizacja, zarządzanie. Polskie Wydawnictwa Ekonomiczne, Warszawa.

Knapik R., 2008. Przewodnik geoturystyczny po Karkonoskim Parku Narodowym. Karkonoski Park Narodowy, Jelenia Góra.

Knapik R., 2011a. Przewodnik po ścieżce geoturystycznej we wschodnich Karkonoszach. Karkonoski Park Narodowy, Jelenia Góra.

Knapik R., 2011b. Mineraty polskich Karkonoszy, Karkonoski Park Narodowy, Jelenia Góra.

Knapik R., Jała Z., Sobczyk A., Migoń P., Aleksandrowski P., Szuszkiewicz A., Krąpiec M., Madej S., Krakowski K., 2011. Inwentaryzacja $i$ waloryzacja geostanowisk Karkonoskiego Parku Narodowego i jego otuliny oraz wykonanie mapy geologicznej tego obszaru. Available from: https://www.mos.gov.pl/g2/big/2010_09/e38c6e5ddc05a09a1105cc45ab1ea85d.pdf [accessed: 2014.03.30].

Knapik R., Migoń P., 2010. Karkonoski Park Narodowy z otuliną jako geopark krajowy. Przeglad Geologiczny, 58: 1065-1069.

Koszela S., Marek A., 2013. Geotourist attractions of the Kleśnica Valley. Geotourism/Geoturystyka, 32-33: 13-24.

Kozłowski S., Migaszewski M., Gałuszka A., 2004. Geodiversity conservation - conservating our geological heritage. In: Ber A., Alexandrowicz Z. (eds), Geological heritage concept, conservation and protection policy in Central Europe. PIG-PIB, Special Papers, 13: 13-20.

Łodziński M., Mayer W., Stefaniuk M., Bartuś T., Mastej W., 2009.
Geotourist attractions of the West Sudetic Geostrada. Geoturystyka, 19: 19-42.

Marszałek H., Rysiukiewicz M., Wąsik M., 2008. Geotouristic significance of selected springs in the Sudetes. In: Solecki A.T. (ed.), Geoeducational potential of the Sudety Mts. Fundacja Ostoja, Wrocław, 113-123.

Mateo-Rodriguez J.M., 2003. La idea del paisaje en el turismo de los sociedades y turismo modernas. Tetos y alternativas. In: Capacci A. (ed.), Paisaje, ordenamiento territorial y tourismo sostenible, Genova, 125-134.

Medlik S., 1995. Leksykon podróży, turystyki, hotelarstwa. PWN, Warszawa.

Melisidou S., Papageorgiou A., Papayiannis D., Varvaressos S., 2014. Tourism clusters as a potentially effective tool for local development and sustainability. Journal of Tourism Research, 9: 218-232.

Mianowicz K., Brzozowska K., 2009. Potencjał geoturystyczny Wojcieszowa (Góry Kaczawskie). In: Dudkowski M. (ed.), Problemy turystyki i rekreacji, t. 2: 19-24.

Migoń P., 2012a. Geoturystyka. PWN, Warszawa.

Migoń P., 2012b. Karkonoski Park Narodowy - skaty i krajobraz. Karkonoski Park Narodowy, Jelenia Góra.

Migoń P., 2012c. Geographical setting and general landscape. In: Kasprzak M., Migoń P. (eds), Góry Stołowe. Geology, Landforms, Vegetation, Patterns and Human Impact, Uniwersytet Wrocławski, Wrocław, 5-7.

Migoń P., 2014a. Rediscovering geoheritage, reinventing geotourism: 200 years of experience from the Sudetes, Central Europe. Geological Society London Special Publications.

Migoń P., 2014b. Atrakcje geoturystyczne Krainy Wygastych Wulkanów. Stowarzyszenie LGD Partnerstwo Kaczawskie, Mściwojów.

Migoń P., 2014c. Góry i Pogórze Kaczawskie. W Krainie Wygastych Wulkanów. Ilustrowany przewodnik z mapami. Wydawnictwo Turystyczne „Plan”, Jelenia Góra.

Migoń P., 2014d. Góry i Pogórze Kaczawskie. W Krainie Wygasłych Wulkanów. Mapa turystyczna. Skala 1:50 000. Wydawnictwo Turystyczne "Plan", Jelenia Góra.

Migoń P., Pijet-Migoń E., 2010. Problemy udostępniania turystycznego obiektów wulkanicznego dziedzictwa Ziemi na przykładzie Pogórza Kaczawskiego. Zeszyty Naukowe Wyższej Szkoły Bankowej, 17: 129-151.

Miśkiewicz K., Doktor M., Słomka T., 2007. Scientific bases of geotourism - outline of issues. Geoturystyka, 11: 3-12.

Newsome D., Dowling R.K., 2010. Geotourism: The Tourism of Geology and Landscape, Goodfellow Publishers, Oxford.

Nita J., Myga-Piątek U., 2014. Geotourist potential of post-mining regions in Poland. Bulletin of Geography - Physical Geography Series, 7: 139156.

Pijet-Migoń E., Migoń P., 2009. Projekt „W krainie wygasłych w wulkanów" szansą dla rozwoju turystyki zrównoważonej na Pogórzu Kaczawskim, In: Marak J., Wyrzykowski J. (eds), Rola turystyki w gospodarce regionu, vol. II. Ustugi turystyczne jako podstawa gospodarki turystycznej, 338-345.

Pulinowa M., 2000. Ścieżka Skalnej Rzeźby w Górach Stołowych-przewodnik po ścieżce dydaktycznej. Park Narodowy Gór Stołowych, Kudowa-Zdrój.

Roberts B., 2000. Benchmarking the Competitiveness of the Far North Queensland Regional Economy. Queensland University of Technology, Brisbane.

Rogowski M., 2014. Produkty geoturystyczne Sudetów jako unikatowa oferta regionu. Studia Periegetica, 12: 93-108

Rogowski M., Bronowicki S., Machnicka M., 2013. Atrakcyjność turystyczna geostanowisk Geoparku Karkonosze. Studia Periegetica, 2: 109-126.

Różycka K., 2014. Atrakcyjność geoturystyczna okolic Wojcieszowa w Górach Kaczawskich. Przegląd Geologiczny, 62: 514-520.

Słomka T., Doktor M., Bartuś T., Mastej W., Łodziński M., 2009. Geotourist attractions of the Eastern Sudetic Geostrada. Geoturystyka, 19: 61-72.

Stach E., 2014. Turystyka i edukacja w obiektach geologicznych na przykładzie kompleksu Osówka w Górach Sowich. Prace Komisji Krajobrazu Kulturowego, 26: 189-199.

Stasiak A., 2006. Produkt turystyczny - szlak. Turystyka i Hotelarstwo, 10: 9-40.

Staszek W., 2014. Wybrane geostanowiska na terenie Dolnego Śląska jako czynnik rozwoju geoturystyki. In: Kołodziejczyk K., Chylińska D., Zaręba D. (eds), Studia krajobrazowe, Tom 4B, Krajobraz jako nośnik idei. Ujęcie analityczne, 223-235.

Štursa J., 2013. The development of opinions on the geo-biodiversity of the Giant Mountains' arctic-alpine tundra and its conservation. Opera Corcontica, 50: 55-74. 
Tourism 2020 Vision. Global Forecasts and Profiles of Market Segments, 2001. World Tourism Organization, vol. 7, Madrid.

Wojewoda J., 2011. Geoatrakcje Gór Stołowych - przewodnik geologiczny po Parku Narodowym Gór Stołowych. Park Narodowy Gór Stołowych, Wrocław.

Wojewoda J., 2013. Mapa geoatrakcji krainy Gór Stolowych i Broumovskich Sten. Wydawnictwo Turystyczne „Plan”, Radków.

Wojewoda J. (ed.), 2013. Geoatrakcje okolic Radkowa. Radków.

Wyrzykowski J. (ed.), 1991. Ocena krajobrazu Polski w aspekcie fizjonomicznym na potrzeby turystyki. Uniwersytet Wrocławski, Wrocław.

\section{Websites:}

www 1 - Geoparky na území ČR, http://www.geology.cz/narodnigeoparky\#krkonose [accessed: 2014.03.30]

www 2 - Partnerstwo Kaczawskie Kraina Wygasłych Wulkanów, http:// www.gorykaczawskie.pl/pl/o-nas [accessed: 2014.03.30] www 3 - Lwóweckie Lato Agatowe, http://www.lla.lwowekslaski.pl/strona-1-Lwoweckie_Lato_Agatowe.html [accessed: 2014.03.30]

www 4 - http://www.broumovsko.cz/pl/adrspasske-skaly-1 [accessed: 2014.03.30]

www 5 - Geopark Vnitrosudetská pánev Vižňov, http://www.skola.mezimesti.cz/305-geopark-viznov/ [accessed: 2014.09.30]

www 6 - http://www.pttk-stronie.pl/sciezki-przyrodniczo-dydaktyczne,20. html [accessed: 2014.03.30]

www 7 - www.geostrada.eu. [accessed: 2014.03.30]

www 8 - http://mineralne.pgi.gov.pl/wody-lecznicze.html [accessed: 2014.03.30]

www 9 - http://www.lecebne-lazne.cz/cs [accessed: 2014.03.30]

www 10 - Podziemne trasy turystyczne, http://www.podziemia.pl/ [accessed: 2014.03.30]

www 11 - http://www.villagreta.pl/en/holidays-mountains-poland/searching-for-minerals [accessed: 2014.03.30] 